Historic, Archive Document

Do not assume content reflects current scientific knowledge, policies, or practices. 



\section{General Information}

\section{PRICES HEREIN CANCEL ALL PREVIOUS PRICE LISTS}

LOCATION-Wne are located midway between Galesburg and Rock Island, and about midway between Galva and Burlington, on the C. B. \& Q. R. R., therefore can ship in any direction.

Our grounds are located opposite the depot, our office and packing sheds adjoining the tracks, which makes delivery very convenient and without delay.

SHIPPING-We have extra good shipping facilities. Four local freights and eight express trains each day. We will ship all small packages by Express or Parcel Post, and recommend the larger packages to be sent by Express, even if the cost is a trifle more than freight, thus insuring immediate delivery.

TERMS-Cash or satisfactory references from unknown parties before shipment.

PACKING-These prices are for well packed stock, and delivered to the railroad station at ALPHA.

MISTAKES cheerfully corrected, but no claims allowed unless made within seven days after shipment is received.

GUARANTEE-We guarantee all Nursery stock to be true to name, and should any prove not, we will return the amount paid for such stock, or replace with stock that is true, but we are not liable for damages other than herein named.

REPLACING-We do so at one-half the original price on fruit trees and shrubs, providing a list of the varieties that did not grow is sent to us within four months after the stock is received. Otherwise we do not.

RATES-Six at dozen, 50 at 100 rates, unless otherwise stated. This applies to trees, plants, etc., of any one class having a common price.

SHIPPING TIME-Spring shipments start about the first week in April and continue until last of May. Fall shipment starts about the middle of October and continues until freezing weather.

SUBSTITUTION-We desire to follow the customer's wishes and will not substitute unless we are out of the varieties ordered, and then to our best judgment, unless advised otherwise.

DISEASE-Our stock and premises are inspected each year by a State inspector, and a certificate issued, that such are apparently free from all dangerous insects and diseases. A certificate of inspection accompanies each shipment. 


\section{Plan to Plant Another Tree}

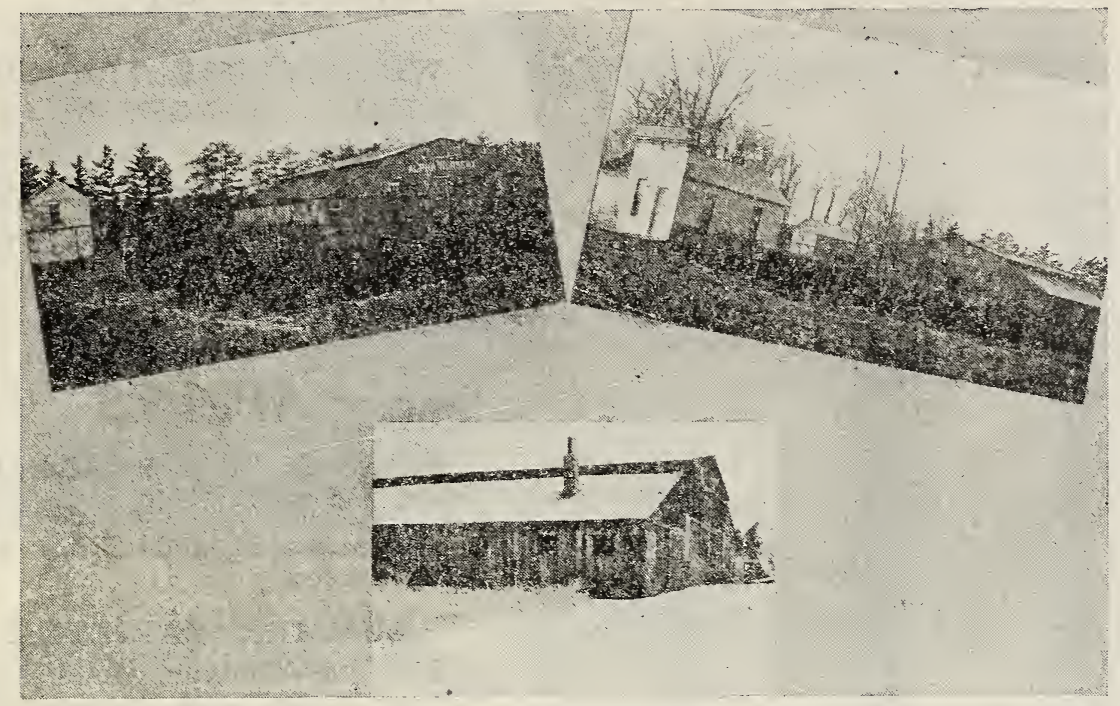

Office and Part of Packing Sheds

\section{Alpha nursery Stock}

I S grown on heavy, rich black loam, which insures good, strong, steady growth. Our aim is to grow the very best, most hardy and productive varieties adapted for the Northern central states.

$W^{\mathrm{E}}$ have been in the nursery business at Alpha, Illinois, for the past 31 years, and have a host of satisfied customers, as we try our best to treat every one fairly and squarely.

W E try to serve every customer and planter of our goods so promptly, courteously, and thoroughly as to assure each the profit, pleasure and satisfaction he expects.

$W^{\mathrm{E}}$ ask you to call and inspect the Nursery at any time, more especially during April if in the market for Nursery stock, as at that time you can select the stock you wish, which can be taken with you or shipped, as you wish. We will try and show you the best of treatment in every way.

ALPHA NURSERY STOCK is backed by QUALITY, SERVICE AND SATISFACTION. 


\section{PRICES HEREIN CANCEL ALL PREVIOUS LISTS}

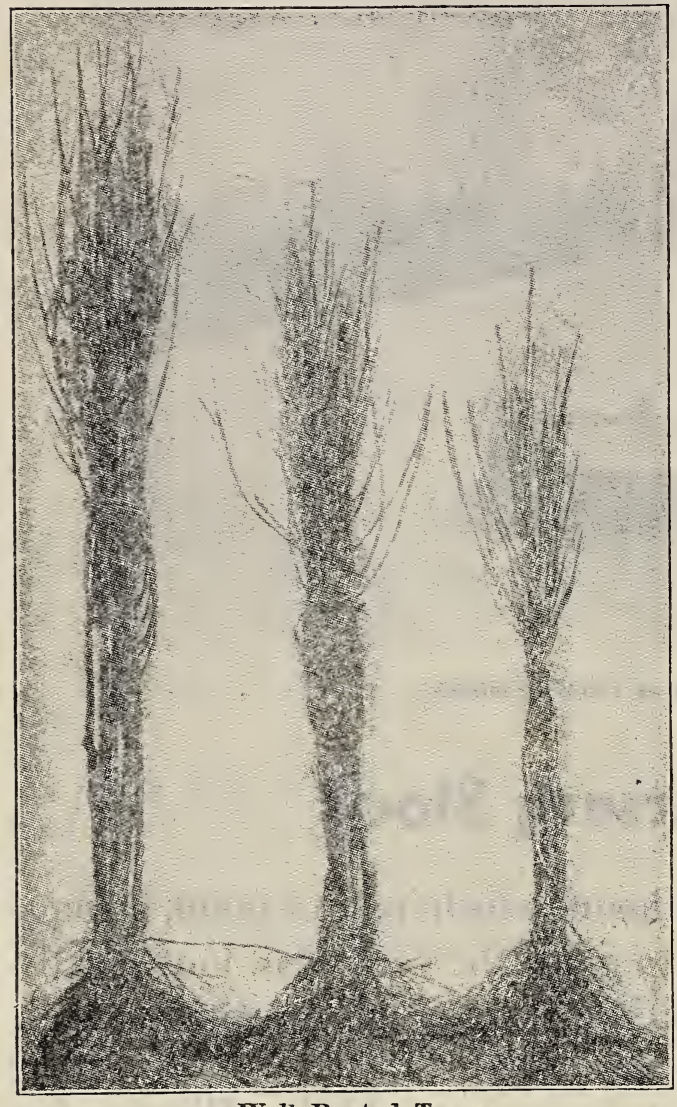

Well Rooted Trees

WE PAY THE TRANSPORTATION CHARGES on all orders, amounting to $\$ 15.00$ or over, if east of Colorado. Except on large shade trees, we will use our judgment how to send the shipments.

\section{APPLES}

First class, 4-6 ft., $50 \mathrm{c}$ each; 10 or more, $45 \mathrm{c}$ each.

See pages 31 and 32 for small sized apples.

\section{SUMMER VARIETIES}

Benonia-Medium, roundish, pale yellow, shaded with crimson; juicy, tender, sub-acid; August.

Early Harvest-Medium, to large, roundish, bright straw color, flesh white, July. Good üuality.

Astrachan Red-Large, roundish, nearly covered with crimson; juicy, sub-acid; tree strong, spreading grower. August.

Red June-Medium, o b 1 o n g. hardy and productive; deep red color; flesh white, with tender, rich, sub-acid. August.

Yellow Transparent-M e di u m, yellow, good quality, productive, excellent; bears early. July.

Liveland Raspberry-A very early variety of fine quality, good size, white striped and shaded crimson; a good healthy grower, very hardy.

\section{AUTUMN VARIETIES}

Dyer-Good size, pale yellow, very tender and juicy, extra good quality. A good bearer; tree medium grower and hardy. October.

Duchess-Large size, roundish, streaked with red and yellow, flesh white, juicy, acid. September.

Famuese (Snow)-Medium, deep crimson; flesh snowy white, tender. Tree slow, crooked grower. October and November.

Golden Sweet-Fruit large, pale yellow; flesh tender, sweet and rich; hardy and a good grower. August and September.

Wealthy-Large, roundish, smooth, nearly covered with dark red; flesh white, fine, juicy, sub-acid, quality very good; good grower and productive. October. 


\section{APPLES}

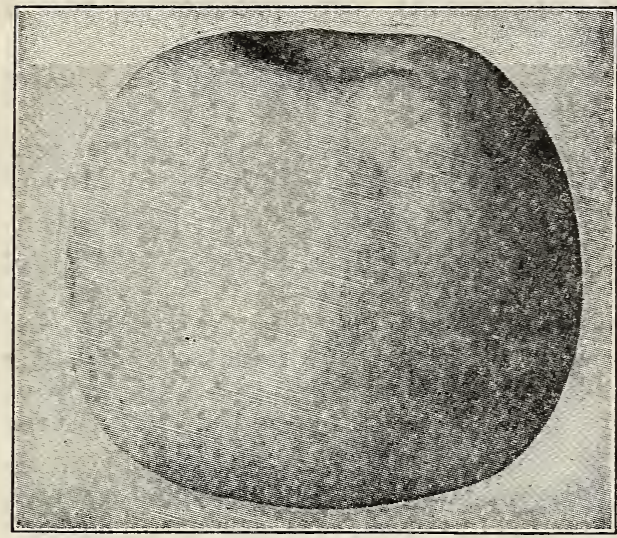

Grimes Golden

\section{WINTER VARIETIES}

Ben Davis-Large, handsome, striped; good, hardy, vigorous and productive; late keepers; very showy. December to March.

Baldwin-Medium size, red; flesh yellow, sub-acid; tree a good grower but a little tender here. December.

Black Ben Davis-Much like Gano in tree and fruit.

Grimes Golden Pippin-Medium golden yellow, with white dots, crisp, tender and juicy, excellent; tree vigorous, hardy and productive. November to January.

Jonathan-Medium, red and yellow; very showy, juicy, excellent; tree slender and spreading; bears early. November to February.
Mammoth Black Twig -Large, deep red, subacid; early and abundant bearer; keeps well; tree a strong grower; resembles Winesap, but is superior in many ways, and fully one-third larger. January to April.

Delicious-Fruit large, nearly covered with brilliant dark red, flesh fine grained, crisp and melting, juicy with a delightful aroma; of very highest quality. December to February.

Gano- Good size, smooth and very attractive; deep red, resembles Ben Davis, but is an improvement on that variety, being handsomer and better colored. December to March.

Northwestern Gr e e ning- Large, smooth, greenish yellow; flesh fine grained, firm; extremely hardy and a strong, handsome grower. December to April.

Paradise Sweet-Medium size, greenish yellow, sweet, good quality. December.

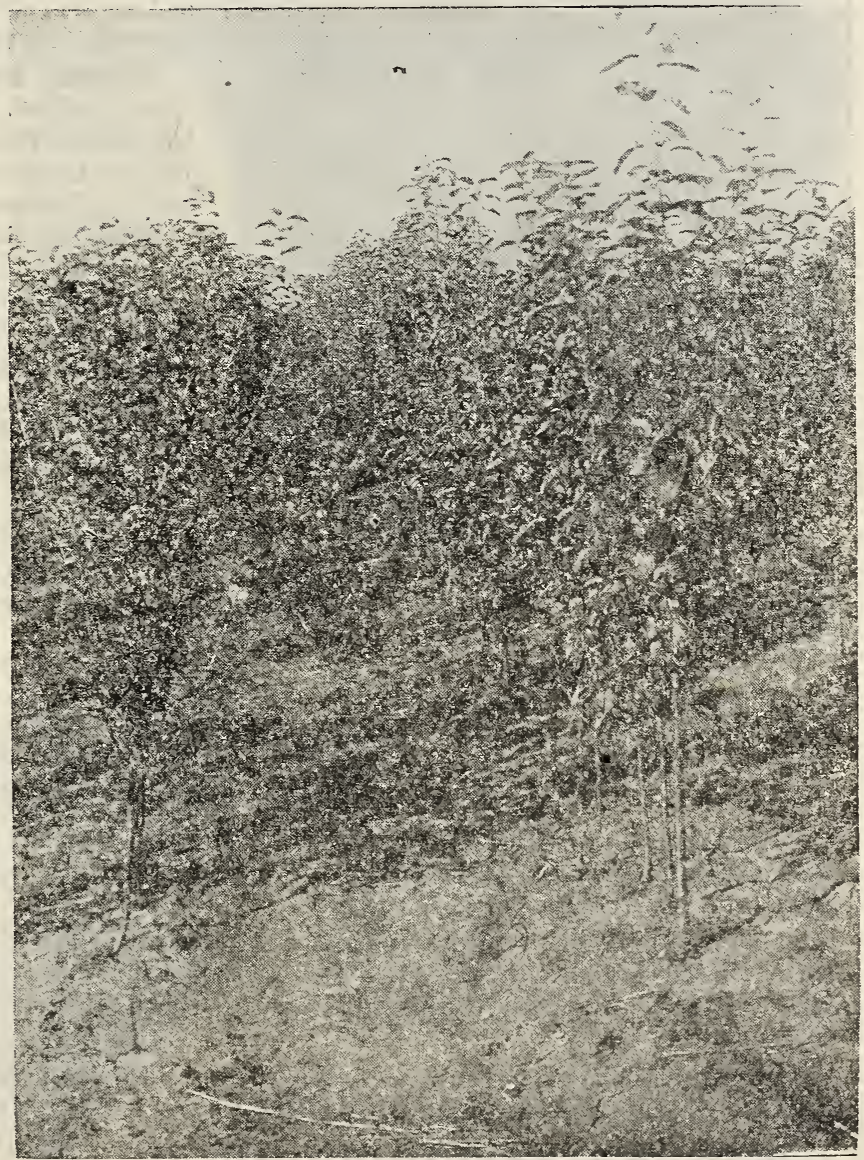

Apple lirees in Nursery 
Roman Stem-Medium size, yellow, of good quality, very productive; tree a slow grower when young.

Golden Russet-Medium size; flesh greenish white, good quality; tree a good grower and hardy. January.

Salome-Medium, yellow and red, very handsome; flesh whitish yellow, tender, slightly aromatic; tree hardy; vigorous, upright grower. January to May.

Stayman's Winesap-Fruit large, striped, nearly covered with red; flesh greenish yellow, very juicy and aromatic; very good; a strong, spreading grower; a good, early bearer; the best of our late winter apples. January to May.

Seedless-This apple originated in New Mexico in 1908. Mr. Wirt was able to get three trees at that time which are now in bearing. We have propagated a few trees and offer them for sale; the fruit is red, striped slightly with yellow. There are no seeds and many of the apples have no core. Good keeper. Tree hardy and good grower. December to March. 4 to $6 \mathrm{ft}$., $\$ 1.00$ each.

King David-Medium size, dark red;

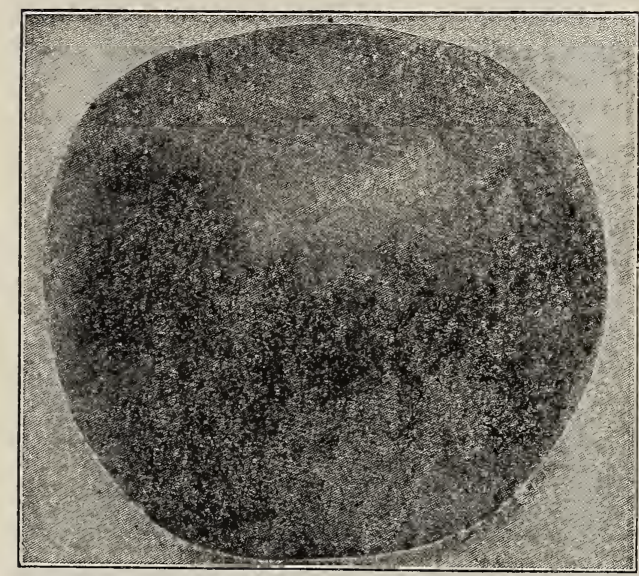

Stayman's Winesap tree hardy and good grower. December.

Tallman Sweet-Medium, pale yellow, firm, rich and very sweet, the most valuable preserving and baking apple; vigorous. October and December.

Winter Banana-Fruit large, color clear yellow, overspread with pink; redblushed; flesh yellow, very rich and juicy; tree subject to blight. November to January.

Winesap-Medium, roundish, deep red, firm, crisp, juicy, excellent quality, moderate grower and good bearer; succeeds well throughout the West. December to May.

Yellow Bellflower-Large size, pale yellow, flesh white, sub-acid; tree a good grower; rather shy bearer. December.

Golden Winesap-Niew Variety, one of the most promising offered in the past twenty years. Color yellow with a slight red blush, juicy flavor of the Jonathan, and the meatiness of the old Winesap, good size, and good keeper abundant bearer, December to March, 4 to $6 \mathrm{ft}$. trees, $75 \mathrm{c}$ each.

\section{CRAB APPLE}

First class; 4 to $6 \mathrm{ft}$. trees, $50 \mathrm{c}$ each.

Transcendant-Large, golden yellow with blush; flesh firm, crisp, yellowish; fine grained, very juicy and acid. Popular for jelly and preserves. Trees grow rapid and irregular; great bearer.

Hyslop-Large, round, yellow, with heavy shadings of deep crimson; blue bloom; flesh fine, firm, yellow. Its high color always commands a fancy market price. Bears abundantly and in clusters. Tree hardy and vigorous. September, October.

Whitney-Fruit very large, yellow striped with red, flesh yellow, very juicy and fine grained, flavor rich and almost sweet. August.

Sweet Crab-Large size, sweet, good bearer; whitish yellow. Fine for preserves and pickles. September. 


\section{PEACHES}

First class; 4 to $6 \mathrm{ft}$. trees, $50 \mathrm{a}$ each; 6 or more, $45 \mathrm{c}$ each.

Elberta-The great American market peach; produces big, profitable crops. Fruit, large, bright, attractive, yellow, with crimson shading; flesh firm and good. Will ripen perfectly when picked green. Free stone. August and September.

J. H. Hale-It averages one-third larger than the Elberta, ripens earlier, and is much better in quality; color, golden yellow, inside and out, with a red-blushed cheek, a perfect freestone. Ripens August 25th.

Champion-Fruit large, delicious, sweet juicy; skin creamy white, with red cheek; handsome, hardy and productive, and a good shipper; adhering slightly to the stone. August 15 th.

Crosby-Freestone, medium size, bright yellow, streaked with carmine; annual bearer; hardy. September 15 th.

Lemon Cling-Very large, light yellow; flesh firm, yellow and rich; the great canning peach of the South and West. August.

Greensboro-The flesh is white, juicy and delicious quality for so early a peach. The largest and most beautifully colored of all early sorts. July.

Crawford's Early-Freestone, large yellow; flesh yellow, quality good; tree good grower, but the buds are tender. September.

Lovell Seedling-The great California drying peach; medium size, yellow; good bearer. Seedlings of this sort generally bear when other varieties are a failure. $3 \mathrm{ft}$. trees, $30 \mathrm{c}$ each.

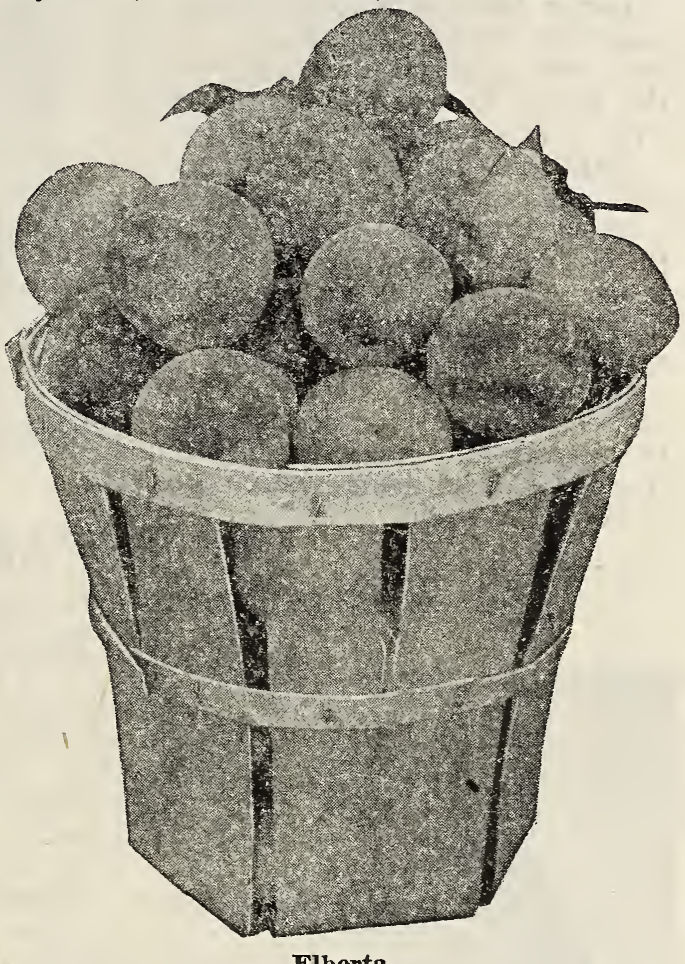

Elberta

PRUNES

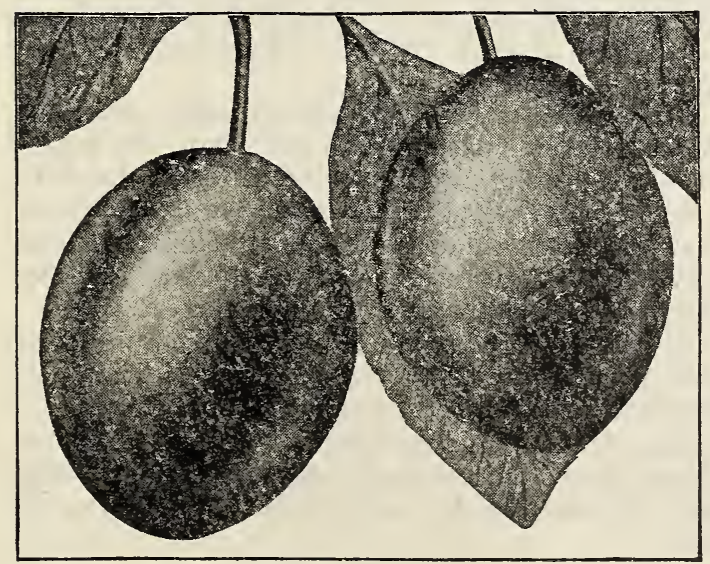

Italian Prunes
4 to $5 \mathrm{ft}$. straight trees, not branched. $75 \mathrm{c}$ each

Italian Prune-Medium large; purplish-black; blue bloom; free; flesh greenish-yellow, juicy, sweet, and of good quality will hang on tree after ripening; splendid for drying, canning, and market. Tree very productive. September.

We have had considerable call for Italian Prunes the past season, as they are becoming more and more one of the popular canning fruits. They are hardy here and require the same treatment as the plum. We have secured a few hundred trees for spring delivery and suggest you place your order early for this item. 


\section{CHERRIES}

5 to $6 \mathrm{ft}$., first class, $\$ 1.00$ each; 6 or more, $90 \mathrm{c}$ each

Early Richmond-Medium, red, early, hardy, immensely productive; ripens the last of June.

Large Montmorency-Large; fruit beautiful dark red, sub-acid; of the very best quality; ten days later than the Early Richmond; a fine shaped tree; hardy and productive.

English Morello-Fruit large, very dark red, nearly black; tender, juicy, acid, rich, of good quality. Owing to its rich, red color, looks much better when canned than Early Richmond. Tree dwarf, slender and spreading. Little tender here.

Compass-Cross between a cherry and a plum. Fruit good size, bright red, sweet and juicy, of fine flavor. A good early bearing tree, perfectly hardy. $75 \mathrm{c}$ each.

\section{PEARS}

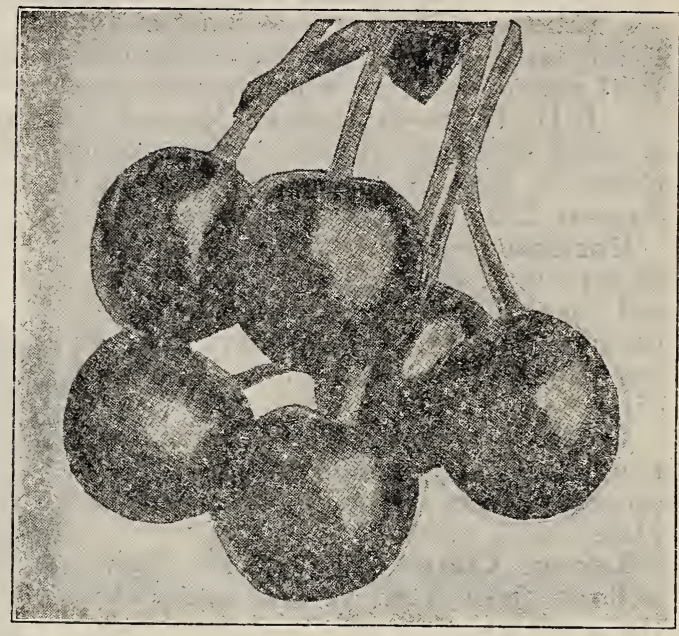

Earty Richmond

4 to $6 \mathrm{ft}$., first class, 80 cents; 6 or more, $75 \mathrm{c}$ each

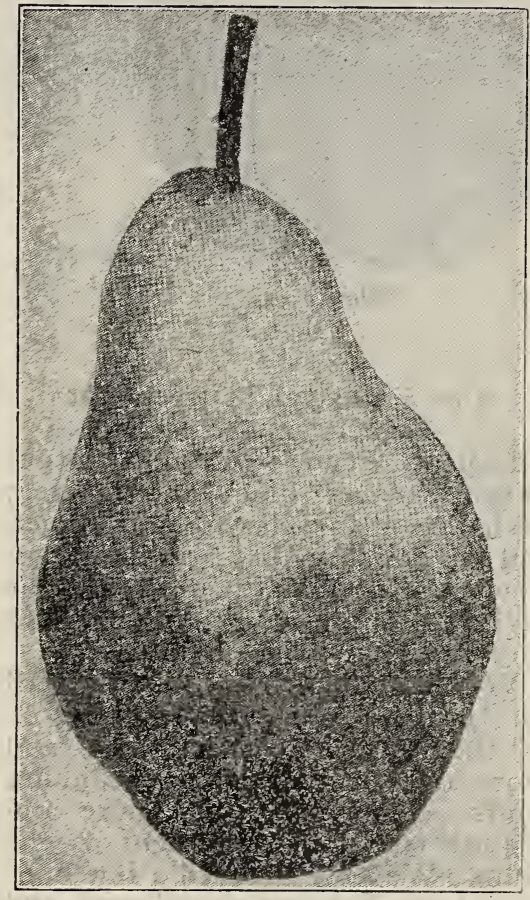

Keiffer Pear

Keiffer-While not of the best quality, it is one of the favorite varieties for canning and preserving. A very profitable market sort on account of its good keeping and shipping qualities. Of extraordinary size and beauty.

Bartlett-Large size color rich yellow, with often a beautiful blush next the sun; buttery, very juicy, and highly flavored. September.

Duchess-Very large; dull, greenish yellow, streaked and spotted with russet; flesh white, buttery and very juicy, with a rich and very excellent flavor. October.

Lincoln-Large; golden yellow; quality only medium, distinctive as having very few if any seeds, almost clear of core. Tree good grower and productive.

Anjou (Buerre D'Anjou)-Large; greenish, shaded with russet-crimson; flesh is highly flavored, vinous and rich. October to January.

Seckel-Small, yellow, with crimson cheek; flesh melting sweet and aromatic; most exquisitely flavored pear known. Tree slow grower, but hardy and healthy. September.

Worden (Worden's Seckel)-Medium size; golden yellow, with russet cheek; flesh fine grained, juicy. Tree hardy. September.

Dwarf Pears-Bartlett, Duchess, Seckel. These pears commence bearing much earlier than the standards. 4 to $5 \mathrm{ft}$. trees, price $75 \mathrm{c}$ each. 


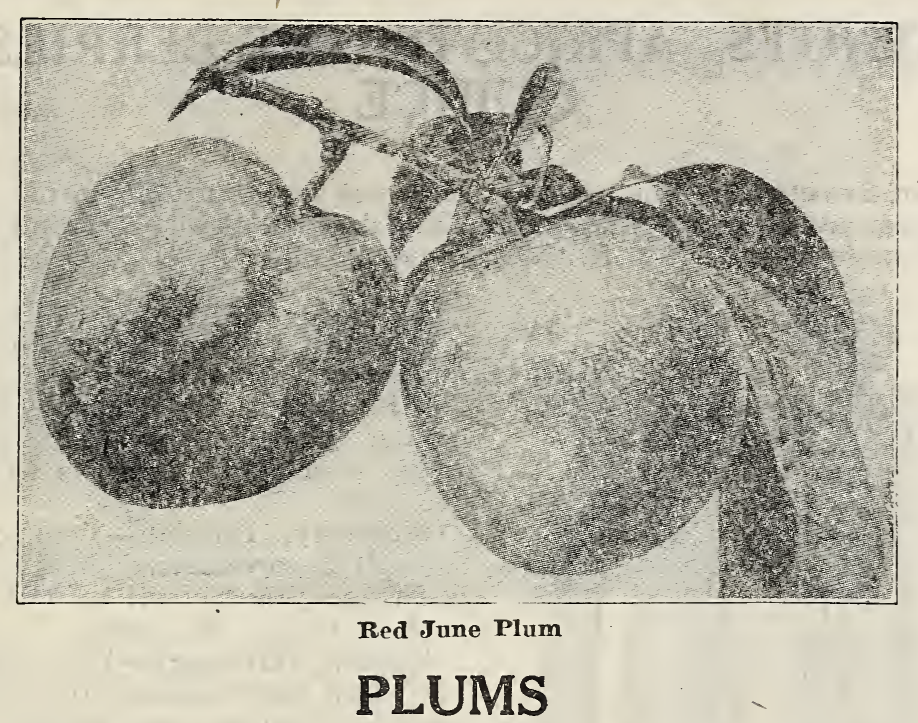

First class, 4 to $6 \mathrm{ft}$. trees, $85 \mathrm{c}$ each; 6 or more, 804 each See Page 5 for Italian Prunes

Abundance-Medium size, showy; beautiful amber colored, turning to a rich, cherry, highly perfumed; flesh light yellow, exceedingly juicy and tender. July.

Burbank-Very large, reddish purple; flesh yellow and solid; cling, fine quality, one of the best for canning; tree strong, spreading grower, hardy and productive; subject to rot in wet years. August.

Red June-A vigorous, hardy, upright, spreading tree; as productive as abundance. Fruit medium to large, deep vermilion red with handsome bloom; very showy, flesh light lemon color, slightly sub-acid, of good and pleasant quality; pit small. Early.

Green Gage-Medium sized yellow freestone, of extra good quality; tree a slow, dwarfish grower. August.

Wild Goose-Hardy, native, deep red with purplish bloom; flesh yellow, juicy and sweet; rapid grower; early and abundant bearer. July and August.

Yellow Egg-Fruit large, yellow, fair quality; fine for canning; tree a good grower and very productive; the best of the yellow plums for this climate. September.

Guii-Fruit large, purplish blue; flesh yellow, firm and sweet; freestone; tree hardy and a strong grower. It has done the best here of any of the large blue plums. September.

Blue Damson-Enormously productive. Fruit small size, about an inch long; skin purple, covered with thick blue bloom; flesh melting and juicy, rather tart, separates partially from the stone. September.

Hanska-Cross between native Plum and Apricot Plum of China, fruit splendid for eating out of the hand and when cooked retains the apricot flavor, fruit about one and one-half inches in diameter, red in color, flesh firm, yellow, good quality. Begins to bear the second year. Hardy.

Sapa-Fruit dark purple, thin skin, red purple flesh. Very fine for eating and cooking, fine flavor and very prolific bearer. Fruit borne in clusters around the stem; trees three years old have borne as high as one and one-half bushels. Hardy. 


\section{TREES and GARDEN ROOTS}

\section{CHESTNUTS, APRICOTS, MULBERRIES and QUINCE}

American Sweet-The nuts of this tree form quite an item in our commerce. They are sweet and delicately flavored. This chestnut is also a grand timber and ornamental shade tree. 5 to $6 \mathrm{ft}$. trees, $75 \mathrm{c}$ each.

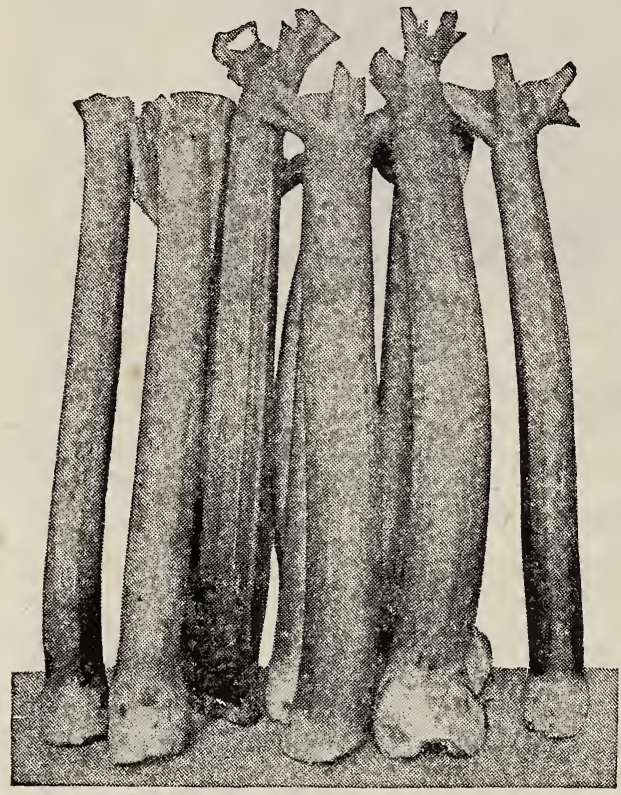

Apricot-The apricot is a very welcome fruit, ripening between the cherry and peach; it requires the same treatment as the plum; good bearer; fruit light orange, flecked with red. Flesh tender, juicy, sweet, and good. 4 to $5 \mathrm{ft}$. trees, $70 \mathrm{c}$ each.

Mulberry, Russian-Tree ornamental, as well as productive; bears very large, handsome black fruit of rich flavor. 4 to $5 \mathrm{ft}$. trees, $50 \mathrm{c}$ each.

Quince (Orange)-The quince is in very high favor because of its many uses, such as canning, preserving, and flavoring other fruits. This variety is golden yellow, flesh firm, of good flavor; bears abundantly; 4 to $5 \mathrm{ft}$. trees, $85 \mathrm{c}$ each.

\section{PIE PLANT}

Linnaeus-Large, early, tender and fine, the very best of all. Large twoyear-old roots, $15 \mathrm{c}$ each; $\$ 1.50$ per 12 ; good two-year roots, $\$ 6.00$ per 100 .

\section{ASPARAGUS}

\section{2-year-old Large Roots}

Conover's Colossal-Produces large tender shoots of vigorous growth. None better. 35c per $12 ; \$ 2.00$ per $100 ; \$ 4.00$ per 500 .

\section{SAGE PLANTS}

The plants are strong, perfectly hardy and increase with age. The leaf is borne well above ground. Strong in flavor and excellent quality. $15 \mathrm{c}$ each; $\$ 1.50$ per 12 .

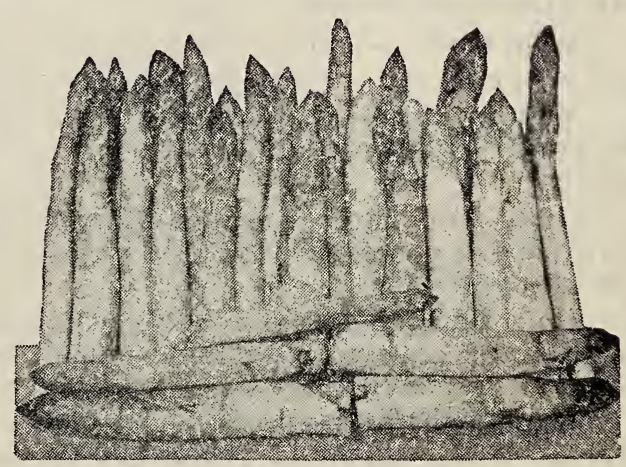

Galesburg, I11.

The trees arrived today in fine shape. I must say they are the nicest trees I have ever received. Please accept my thanks.

JOHN C. BREHM 


\title{
GARDEN FRUITS
}

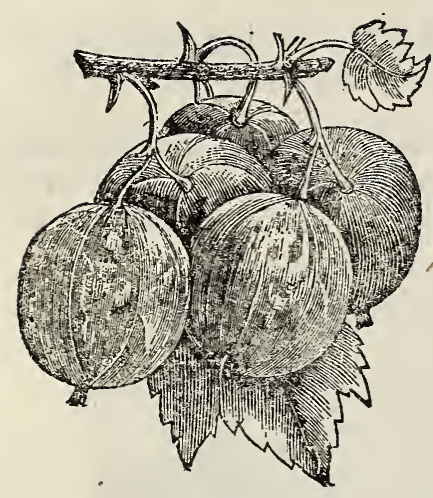

Champion

\section{GOOSEBERRIES}

\author{
30c each; $\$ 3.00$ per 12
}

Champion-A new variety introduced from Oregon, where it originated. Bush a strong, upright grower, very hardy and enormously productive; fruit round, entirely free from mildew and easily gathered. We consider this the best of the gooseberries for general planting.

Pearl-Medium; greenish; quality good; a desirable sort for market also. Bush a strong grower and very productive.

\section{BLACKBERRIES}

Eldorado-Among the good points of this valuable new blackberry are great productiveness, hardiness, extra fine quailty, and sweetness of flavor, without core; the berries are large, jet black, borne in clusters and ripen well together; sweet, melting, rich and pleasant to the taste. Price $75 \mathrm{c}$ per dozen; $\$ 4.75$ per $100 ; \$ 45.00$ per 1,000 .

Snider-Very hardy and productive, of medium size; 75c per $12 ; \$ 4.50$ per 100 .

\section{DEWBERRIES}

Lucretia-A trailing blackberry, larger and juicier than blackberries. Fruit ripens ten days before blackberries. For the best success, cover them in the fall like strawberries; in the spring take the mulching off and put it under them to keep the berries off the ground, and shorten the runners to eighteen inches. Prices, 75 c per $12 ; \$ 4.50$ per 100 .

\section{CURRANTS}

\section{Large 2-year Plants, 20c each;} $\$ 2.00$ per $12 ; \$ 15.00$ per 100

Red Cross-One of the best currants on the market. Ripens in mid-season and produces an enormous quantity of fruit; flavor mild and pleasant. The leaves of the plant are so dense as to hide the canes from view. The growth is very vigorous and hardy. Its good qualities claim for it much popularity.

Cherry-Very large; red, rather acid; bushes short, erect; stout.

Fay's Prolific-Fruit 1 a rg e, bright red, bunches long, productive and hardy; moderate grower.

Black English-Largest a nt best of the blacks.

White-A good grower; berries yellowish white, sweet and mild.

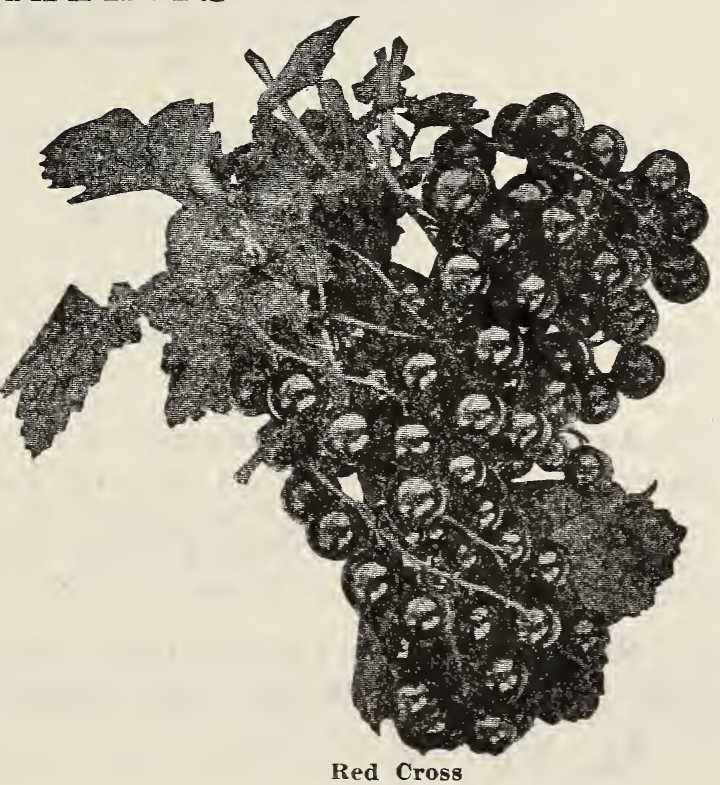


Concord-Black, the most popular grape in America; bunches and berries large, hardy, healthy and productive. 25c each; $\$ 2.50$ per $12, \$ 16.00$ per 100 .

Moore's Early-Black, bunches medium size and very compact; berries large and of excellent quality; ripens ten days before Concord which makes it very desirable for market; very hardy, well suited for the North; one of the best. 30c each; $\$ 3.00$ per 12 .

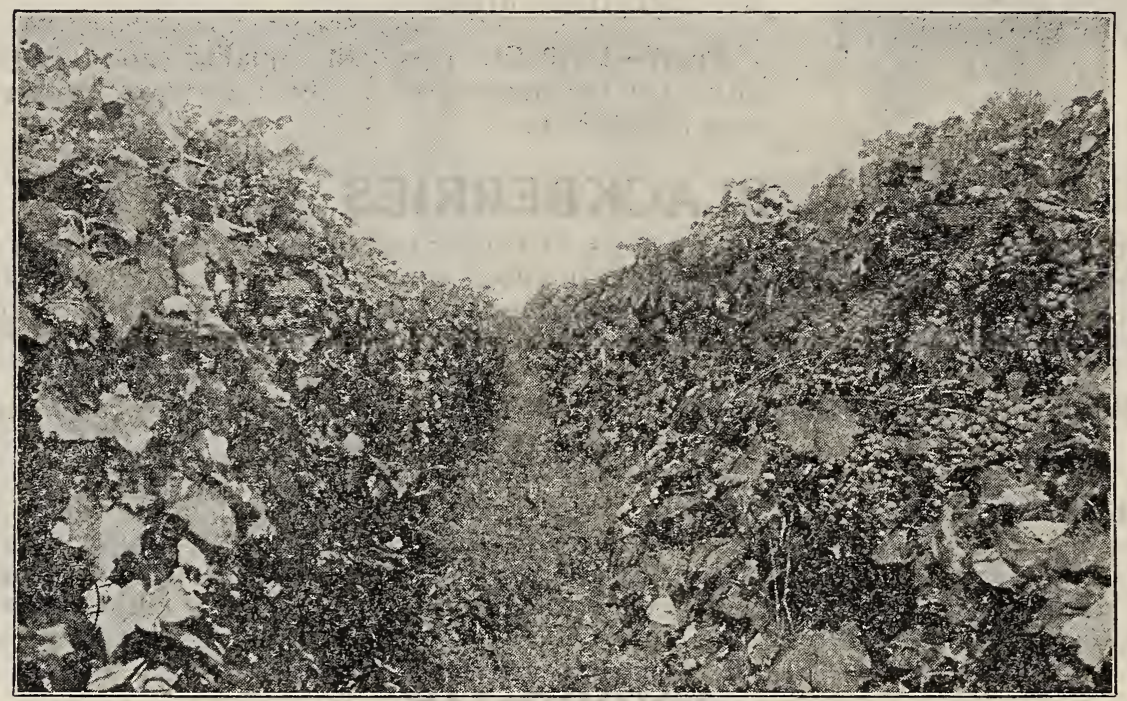

Grapes in Nursery

Campbell's Early-A strong grower, an abundant bearer; bunches and berries very large, glossy black; ripens with the Moore's Early, but will hang on the vines until frost. $40 \mathrm{c}$ each; $\$ 4.00$ per 12 .

Worden (Black)-A seedling of the Concord; bunch large and compact, berry round, black with blue bloom, pulpy, juicy and very pleasant; ripens several days earlier than Concord. 35c each.

Agawam-Red or maroon color; berries large, of rich, peculiar aromatic flavor; ripens a week later than Concord; vine a strong, rank grower. $35 \mathrm{c}$ each.

Moore's Diamond-White, bunches and berries large; flesh tender, juicy, hardy, productive, early; fine quality. $35 \mathrm{c}$ each.

Niagara-Bunch and berries large, greenish white, changing to pale yellow when fully ripe. A little tender here, but hardy farther South. 35c each.

Luti-Early red, extra hardy and strong grower. $35 \mathrm{c}$ each. 
Senator Dunlap, 25 plants, 38 cents; 50 plants, 70 cents; $\$ 1.10$ per 100 ; $\$ 5.15$ per $500 ; \$ 7.50$ per 1,000

Gandy, 25 plants, 65 c; 50 plants, $\$ 1.05 ; \$ 2.15$ per $100 ; \$ 7.25$ per $500 ; \$ 12.00$ per 1,000 Norwood, 25 plants, 80 c; 50 plants, $\$ 1.20$, $\$ 2.45$ per 100

Strawberry plant orders for 500 plants and less will be sent by mail prepaid, over 500 plants by express collect unless the order for nursery stock amounts is $\$ 15.00$ or over. Set the plants out as soon as received.

Write us by Sept. 10 for fall prices.

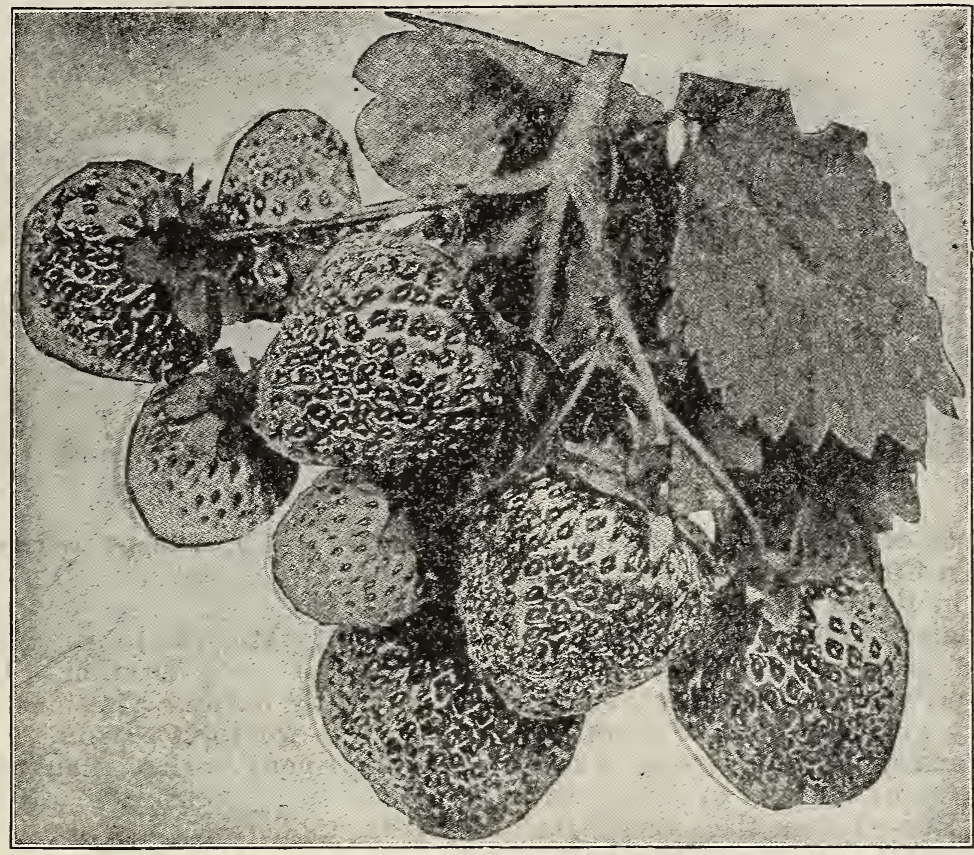

Dunlap strawberry

The following varieties of strawberries are all perfect flowering; that is, they do not need any other variety planted near them for fertilizer. We tie all strawberries 25 in a bunch.

Senator Dunlap-Fruit good size, regular form, beautiful bright red; glossy, firm, splendid keeper and shipper; excellent quality; one of the best for canning; ripens early and continues a long time. We consider the Dunlap the best berry that grows. It and the Gandy will cover the season from early to late.

Gandy-Extra large and handsome, firm; the very latest; most all of the crop ripens after the Dunlap.

Norwood-Extra large and of very fine quality; bright red all the way through, a strong, healthy grower; the best of the large fancy berries. Extra fine variety. (Limited number of plants.)

\section{EVERBEARING STRAWBERRIES}

55 cents per $12 ; 80$ cents per $25 ; \$ 1.35$ per $50 ; \$ 2.65$ per 100

This kind of strawberries have proved a success. They are hardy and healthy, make a crop in June and another in the fall.

Progressive-Berries large, firm, and good quality; plant a healthy, strong grower and a good plant maker. This plant seems to be a general favorite. With us the June crop was almost as good as the standard varieties. This variety is the original ever bearer and the best of all, and will give the best satisfaction. 


\section{ORDER RASPBERRIES EARLY}

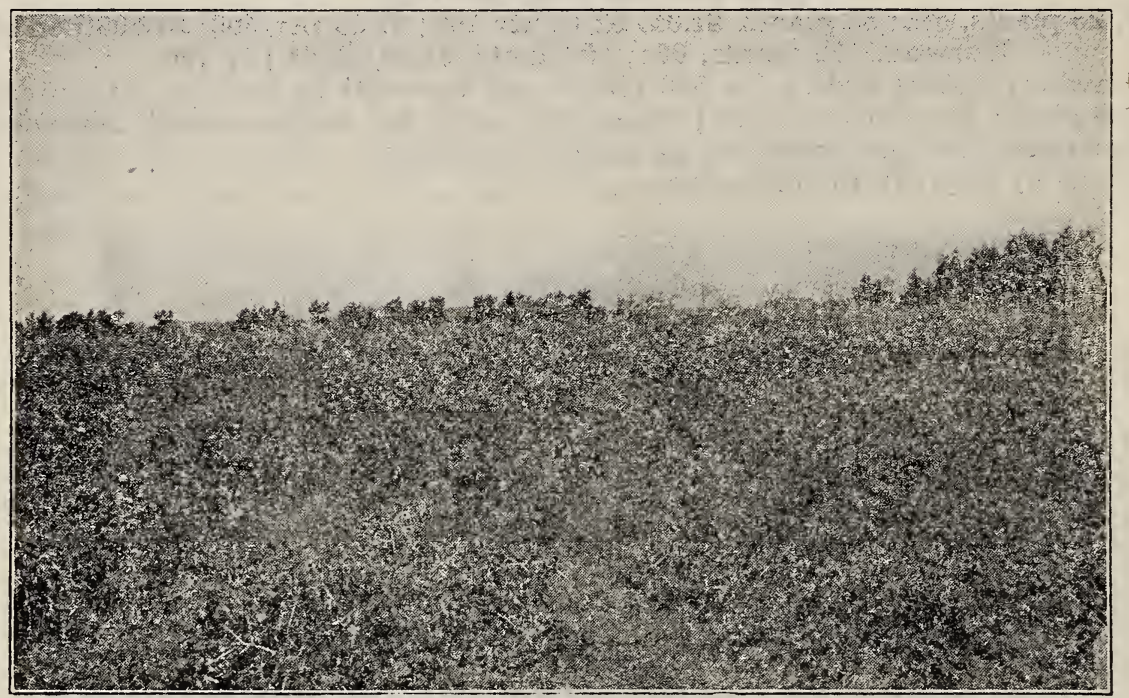

Cumberland Raspberries

1 yr. plants, 50 cents per $12 ; \$ 3.50$ per $100 ; \$ 30.00$ per 1,000 ; except where noted. 2 yr. plants in Cumberland. 75c per 12; $\$ 5.00$ per 100.

2 yr. Plants in Royal Purple, $\$ 1.00$ per $12 ; \$ 6.00$ per 100.

Cumberland-One of the largest black raspberries known; its immense size. firmness and great productiveness entitles it to first consideration. Unusallv strong grower, throwing up stout, stock canes; perfectly hardy. The most profitable raspberry grown for home or market use. Fruits for long season.

Plum Farmer-Black, strong, healthy grower; ripens earlier than the Cumberland and ripens its fruit in a very short time.

Louden Red-Large size, very firm and hardy, moderate grower, the best of the reds for heavy, rich soil. Sprouts.

St. Regis, (Everbearer)-Very early, fruit large and extra quality, good, stocky grower and hardy. It is very much like the Louden except it makes a fall crop on the new canes. Red variety. $\$ 2.50$ per $50 ; \$ 4.50$ per 100 .

Cuthbert-Red, strong grower, fruit large and firm; the best for light soils; sprouts.

Purple Columbia-Deep purplish red, highly flavored, extra strong canes, wonderfully productive; berries very large. There is nothing finer grown in the line of fruit than this variety for table use, canning, etc. This variety does not sprout. 75c per $12 ; \$ 1.50$ per $25 ; \$ 2.50$ per $50 ; \$ 4.00$ per 100 .

Royal Purple-A new variety of great promise. It is a very vigorous grower and very hardy. Fruit purple and delicious for table or canning, and an excellent shipping variety; does not sprout. $75 \mathrm{c}$ per $12 ; \$ 1.50$ per $25 ; \$ 2.50$ per $50 ; \$ 4.00$ per 100 .

\section{READ BEFORE ORDERING RASPBERRIES}

Raspberries should be the first in the fruit line to be planted in the spring. Therefore send in your order for raspberries EARLY, as they should be planted between April 1st and 15th.

Raspberries are tied 25 to the bunch, the top canes are left 6 to 10 inches long for the sole purpose of tying them in bunches, and after planting this cane generally dies, and the plant starts from the crown or root. In planting, spread the roots out good, cover the crown from 2 to $2 \frac{1}{2}$ inches with soil. Do not put manure next to the roots. Cultivate good the first year, then mulch heavy along the row. 


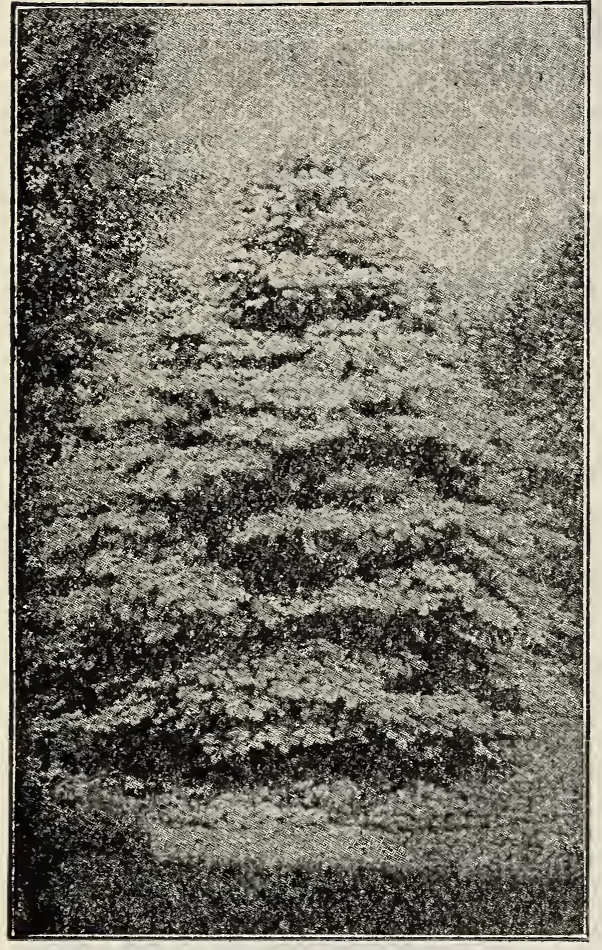

Norway Spruce

\section{ARBORVITIE}

American, or White Cedar-This tree is very unique in its habits of growth, the leaf gradually hardening and forming the wood of the tree; habit upright; much inclined to branch and form more than one trunk; one of the best trees for ornamental hedging.

4 ft. specimens balled and burlaped, $\$ 2.00$ each.

3 ft. specimens balled and burlaped, $\$ 1.50$ each.

2 to $3 \mathrm{ft}$. trees, $90 \mathrm{c}$ each; $\$ 8.00$ per 10 ; 18 to 24 in. trees, $70 \mathrm{c}$ each; $\$ 6.00$ per 10 ; 12 to 18 in. trees, $40 \mathrm{c}$ each; $\$ 3.50$ per 10 ; $\$ 25.00$ per 100 .

\section{SPRUCE}

Norway-A lofty, elegant tree, of perfect pyramidal habit; remarkably elegant and rich; and as it gets age, has fine, graceful, pendulous branches. It is exceedingly picturesque and beautiful. Fine for windbreak; will stand pruning well when used for hedges.

$3 \mathrm{ft}$. specimens balled and burlaped, $\$ 1.75$ each.

$2^{1 / 2} \mathrm{ft}$. specimens balled and burlaped, $\$ 1.25$ each.

2 to $3 \mathrm{ft}$. trees, $90 \mathrm{c}$ each; $\$ 8.00$ per $10 ; 18$ to 24 in. trees, $70 \mathrm{c}$ each; $\$ 6.00$ per 10 ; 12 to $18 \mathrm{in.}$ trees, $45 \mathrm{c}$ each; $\$ 4.00$ per 10.

\section{PINE}

Mugho (Dwarf Mountain Pine) This is the most beautiful of all dwarf pines. It forms a low top with ascending branches, and the breadth of the tree is frequently double its height. Foliage bright green. A valuable tree for ornamental planting. 12 to 18 in., once transplanted, \$2.25 each.

White Pine-The most ornamental of all our native pines; foliage light, delicate or silvery green; flourishes in the poorest soils. 3 to $4 \mathrm{ft}$., $\$ 1.25$ each.

Koster's Blue Spruce-The true Blue Spruce; it is the highest colored and most striking of all evergreens. Foliage rich silver blue; very hardy. Balled with earth. 2 to $2 \frac{1}{2} \mathrm{ft}$. $\$ 7.50$ each.

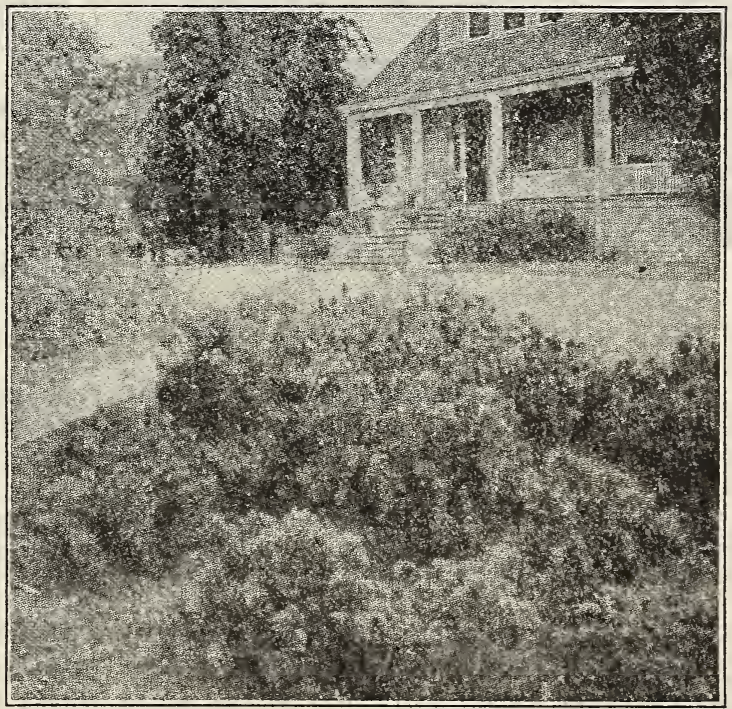

Mugho Pines 
RED CEDAR

Juniperus Virginiana. (M). The fascinating native Red Cedar that is com pared to the classic Cypress. The upright habit, the somber hue of its foliage and the freedom with which it grows in unfertile places are valuable qualities. Splendid for producing natural landscapes. 3 to $4 \mathrm{ft}$., B. \& B., $\$ 2.00$ each; 2 to $3 \mathrm{ft}$., B. $\&$ B., $\$ 1.50$ each; 18 to 24 in., 90 c each.

\section{JUNIPERS}

Irish-Columnar in habit and quite compact in growth. Fine for formal gardening and breaking rounded lines. Foliage bluish-green 2 to 3 ft., B. \& B., $\$ 2.00$ each.

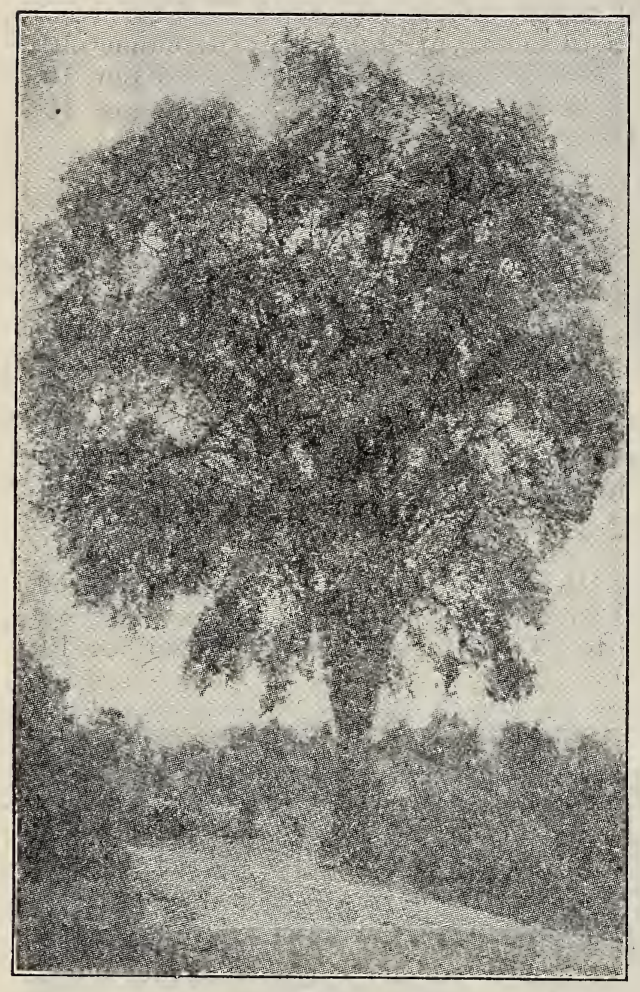

Elm

\section{SHADE TREES}

Popular Norway or Carolina-One of the most rapid growing trees, with large, deep green leaves; succeeds, everywhere, especially adapted to cities, where it makes a fast growth, and resists smoke and gas. It makes a spreading head and dense shade when properly trimmed. 8 to $10 \mathrm{ft}$. $75 \mathrm{c}$ each; $\$ 5.00$ per $10 ; 5$ to $7 \mathrm{ft}$., $40 \mathrm{c}$ each; $\$ 3.50$ per 10 .

Elm-White, the noble, drooping, spreading tree of our woods; one of the grandest of park or street trees. 10 to $12 \mathrm{ft}$., $\$ 1.50$ each; $\$ 12.00$ per $10 ; 8$ to 10 $\mathrm{ft} ., 90 \mathrm{c}$ each; $\$ 7.50$ per $10 ; 6$ to $8 \mathrm{ft} ., 60 \mathrm{c}$ each; $\$ 5.00$ per 10 .

Mountain Ash-A very pretty, small sized tree, with clusters of large orange berries in the fall. 5 to $6 \mathrm{ft}$., $80 \mathrm{c}$ each.

Soft Maple-4 to $6 \mathrm{ft}$., $50 \mathrm{c}$.

Catalpa Speciosa-A rapid grower with large, light green leaves and white flowers in June. 6 to $8 \mathrm{ft}$., $50 \mathrm{c}$.

Norway Maple-A native of Europe; a large, handsome tree, with broad, deep green, shining foliage. Very similar to hard maple, but faster growing. 6 to 8 $\mathrm{ft}$., $\$ 1.25$ each; 8 to $10 \mathrm{ft}$., $\$ 2.00$.

Hard Maple-Spreading top and very dense shade; very desirable for street, park or lawns, 6 to $8 \mathrm{ft}$., $\$ 1.50 ; 8$ to $10 \mathrm{ft}$., $\$ 2.00$.

Schwedler's Maple-Leaves bright red, changing to bronze green during summer; a very attractive tree, with round spreading head. 5 to $6 \mathrm{ft}$., $\$ 2.00 ; 6$ to $8 \mathrm{ft}$., $\$ 3.00$.

Crab (Bechtel's Double Flowering)-A beautiful tree while in bloom; the flowers are fragrant and double, resembling miniature roses, color pink. 2 to $3 \mathrm{ft}$., $65 \mathrm{c}$ each.

Lombard Popular (P. Fastigiata)-Attains a height of from one hundred to one hundred fifty feet; well known for its erect, rapid growth and tall spiry form; indispensable tree for landscape gardening to break the monotony of most other trees. 8 to $10 \mathrm{ft}$., $65 \mathrm{c}$ each; $\$ 6.00$ per 10 .

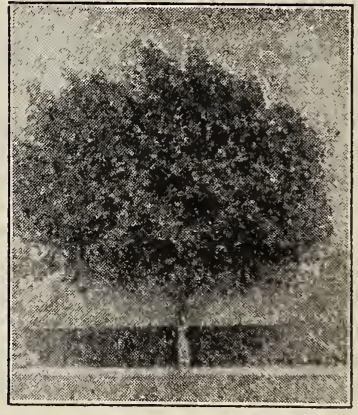

Norway Maple 
Horse Chestnut-White Flowering-A handsome tree of regular form, with showy foliage and covered in the spring with panicles of white, showy flowers marked with red. 4 to $5 \mathrm{ft}$., $\$ 1.25$ each.

Redbud (Cercis) - Judas Tree-A medium sized tree with large irregular head shaped leaves; derives its name, Red Bud, from the profusion of delicate, reddishpink blossoms with which it is covered in early spring before the foliage appears. 5 to $6 \mathrm{ft}$., $\$ 1.25$.

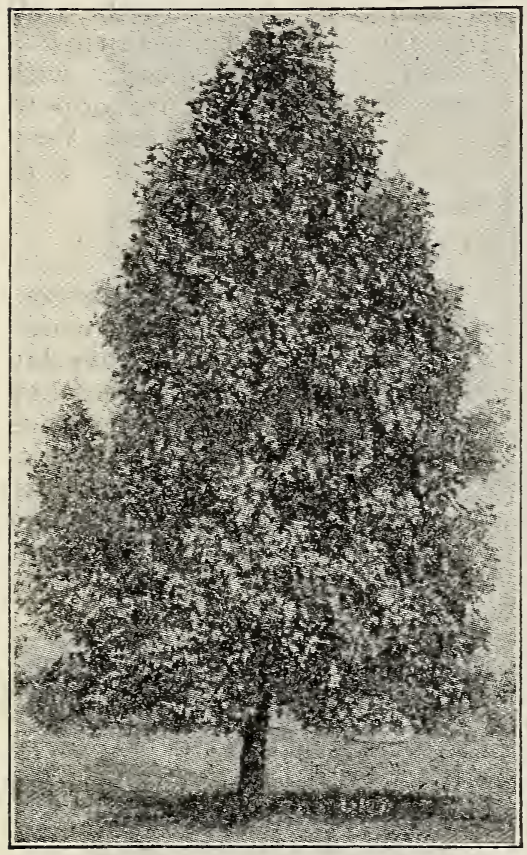

Sycamore

Sycamore-A lofty, wide-spreading tree; heart-shaped leaves; valuable for its handsome foliage and free growth. 5 to $6 \mathrm{ft} ., 75 \mathrm{c}$ each.

Linden, American-A stately tree, growing 60 to 80 feet tall, with large, shining cordate leaves. Valuable for its beautiful white wood; flowers in July. 5 to $6 \mathrm{ft}$., $90 \mathrm{c}$ each.

Maple, Wier's Cut-Leaved-A silver maple with remarkable and beautifully dissected foliage. Of rapid growth; shoots slender and drooping, giving it a very graceful appearance. 5 to $6 \mathrm{ft}$., $75 \mathrm{c}$ each.

Olive, Russian-Tree attains a height of from 20 to 30 feet; bark dark green; wood very heavy and burns like a candle; foliage ' rich silver color, willow shape; flowers deep golden and very fragrant; hardy. 4 to $5 \mathrm{ft}$., 70c each.

Plum, Othello-Purple leaved, a small tree which retains its color well through the summer; open in growth. It is most effective among tall shrubs for color contrast. Small fruit. 5 to $6 \mathrm{ft}$., $90 \mathrm{c}$ each.

Magnolia Glauca-Handsome small tree with long glossy leaves, flower fragrant, about 3 inches across, fruit pink and showy, hardy when well established, needs protection the first two years, grows about 18 feet. $\$ 2.50$ each, 3 to 4 ft.

Catalpa Seedling- $\$ 2.50$ per $100 ; \$ 7.00$ per 500 . These are the hardy Speciosa. For posts they should be planted $4 \times 4$ ft., and given good cultivation for two or three years.

\section{PLAN TO PLANT A TREE}

Fix up the home, the city home and the farm home, a few Trees, Shrubs and Flowers planted around the home will change the looks of things. 


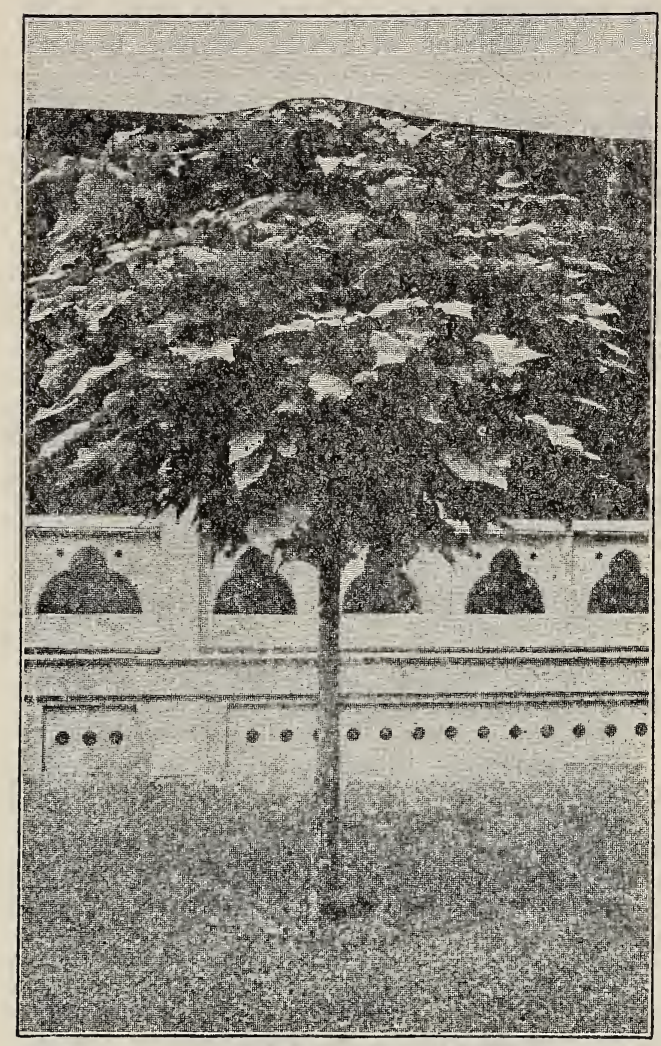

Catalpa Bungeif

Elm. Globe Head-The tree forms a round globe shaped head of its own accord; leaves small and very dark green; this is one of the finest round headed trees we have. Stems $5 \mathrm{ft}$. tall; head 4 yr. $\$ 3.75$ each.

\section{WILLOWS}

Willow, (Salix Caprea) Pussy Willow-A small shrublike tree. Its great charm is in the early spring when each bud changes into a large fur-like catkin. 3 to $4 \mathrm{ft}$., $60 \mathrm{c}$ each.

Willow, Wisconsin (Weeping)-A very graceful tree of large size. Its fresh, bright green tint and long, wavy branches make it very attractive. Very hardy. 5 to $6 \mathrm{ft}$. trees, $50 \mathrm{c}$ each.
Catalpa Bungeii (Umbrella Catalpa) -Grafted on stems six to eight feet high, it makes an umbrella-shaped top without pruning; perfectly hardy; leaves large, glossy, heart-shaped, deep green; lay like shingles on a roof. Stems 3 to $4 \mathrm{ft}$., $\$ 1.00 ; 5$ to $6 \mathrm{ft}$., $\$ 1.50 ; 6$ to 8 ft., $\$ 2.00$.

Tea's Weeping-A variety of the well known Russian Mulberry. Forms a perfect umbrella-shaped head, with long, slender branches which droop to the ground parallel with the stem. Very beautiful and hardy. $\$ 2.50$ each. 5 to $6 \mathrm{ft}$. stems.

\section{CAMPERDOWN ELM}

Leaves are large, glossy dark green. Its vigorous, irregular branches, which have a uniform weeping habit, overlap so regularly that a compact, roof-like head is formed. A strong, vigorous grower, susceptible to training into picturesque form, and considerable utility for canopy shade. The finest Weeping Elm and one of the best weeping trees. $\$ 2.50$ each. 4 to $6 \mathrm{ft}$.

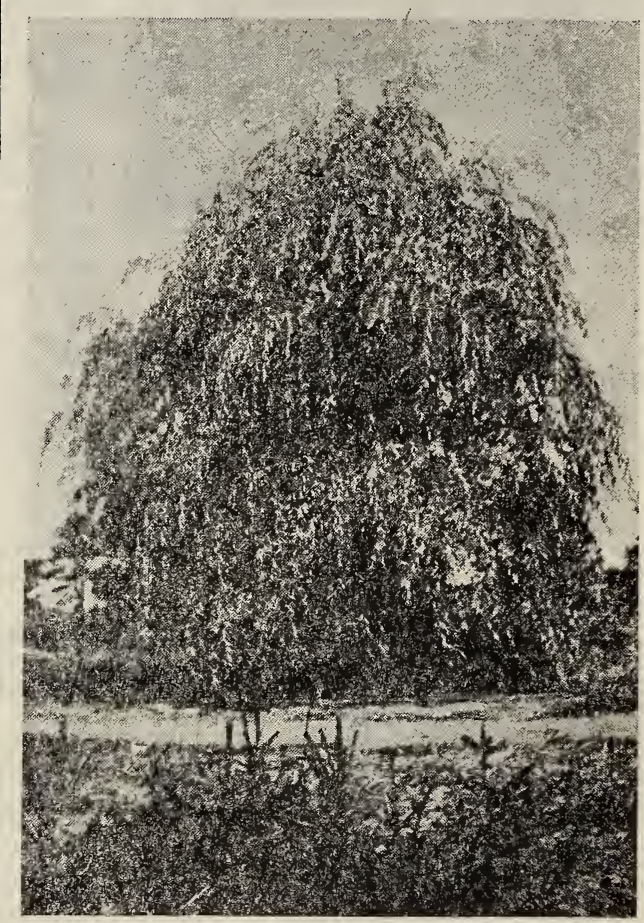

Wisconsin Willow in Nursery 
In the adornment of the home grounds, hardy shrubbery has come to be recognized as indispensable, and it is a pleasure to be able to offer the quality of stock which will be found listed on the following pages. Its uses are many and varied. To set about the foundations of the house, to grow as hedges to divide properties, or as screens to hide unsightly objects, to supplement the planting of evergreens or shade trees, shrubbery has its distinctive place. The proper planting of shrubbery about the home adds to its value many times the amount expended.

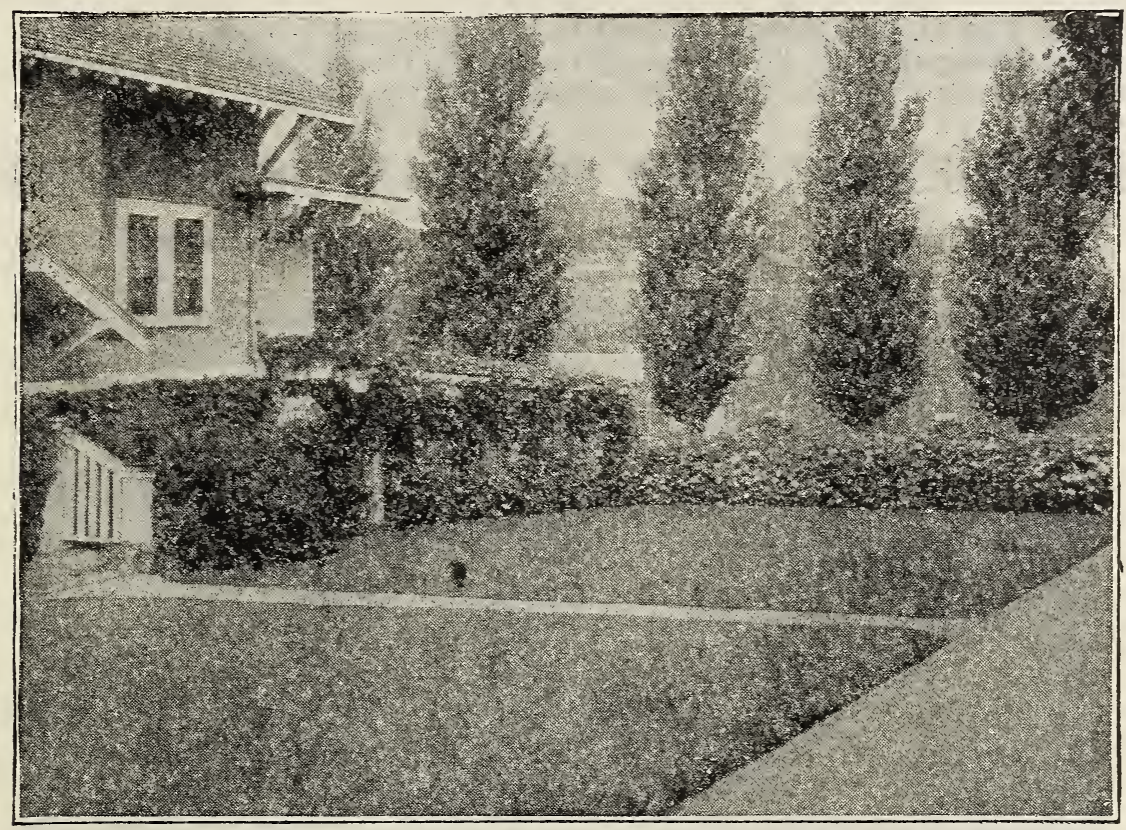

Hydrangias and Lombardii Populars

\section{THE BEST HEDGE AND BORDER SHRUBS}

Barberry (Thunberg's or Japanese)-The finest of all the Barberries, grows in compact form, spiney stems, foliage fine and dense, changing to brilliant red in fall, the clusters of red berries hanging on all winter. Much used for hedge and borders. Considered by many to be the most valuable foreign shrub grown. This Barberry is recommended by the Government. It does not have the wheat rust. 18 to 24 in., $35 \mathrm{c}$ each; $\$ 3.20$ per $10 ; \$ 30.00$ per $100 ; 12$ to 18 in., 30 c each; $\$ 2.80$ per $10 ; \$ 25.00$ per 100 .

Privet Amoors River North-A valuable shrub for hedges and borders, color glossy green, holds its foliage almost the whole year; will stand trimming to almost any extent; perfectly hardy. 2 to $3 \mathrm{ft}$., $30 \mathrm{c}$ each; $\$ 2.50$ per $10 ; \$ 20.00$ per $100 ; 18$ to 24 in., $25 \mathrm{c}$ each; $\$ 2.00$ per $10 ; \$ 17.00$ per $100 ; 12$ to 18 in., $10 \mathrm{c}$ each.

Ibota, Privet-Very much like the above, but

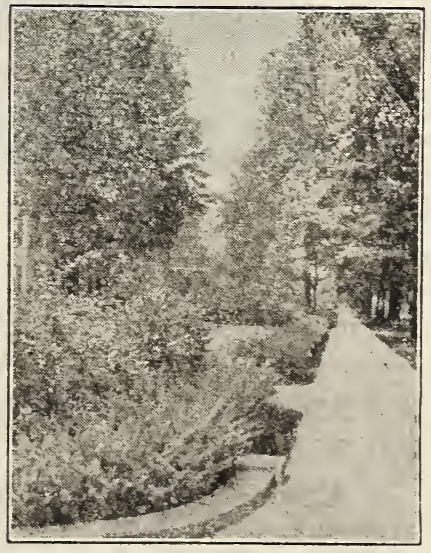

Barberry more spreading in growth; better for screens. Perfectly hardy. 2 to $3 \mathrm{ft}$., 30c each; $\$ 2.50$ per $10 ; \$ 20.00$ per $100 ; 18$ to 24 in., 25 c each; $\$ 2.00$ per $10 ; \$ 17.00$ per 100 . 


\section{HEDGES $\underset{\substack{\text { Flowerinq and } \\ \text { Deciduous }}}{\text { SHRUBS }}$}

\section{HEDGES}

American Arbor Vitea Evergreen-A native of the North; very hardy and will stand shearing well any time of the year; the most popular for hedges and screens, as it keeps green the year round. 12 to 18 in., $40 \mathrm{c}$ each; $\$ 3.50$ per $10 ; \$ 25.00$ per $100 ; 2$ to 3 ft., bushy plants, 90c each; $\$ 8.00$ per 10 .

Spirea Van Houtii (Bridal Wreath)-Used for tall hedges or screens. Has abundance of small white flowers early in the summer. 2 to $3 \mathrm{ft}$., $35 \mathrm{c}$ each; $\$ 3.00$ per $10 ; \$ 25.00$ per $100 ; 18$ to 24 in., 30c each; $\$ 2.50$ per $10 ; \$ 20.00$ per 100 .

\section{FLOWERING AND DECIDUOUS SHRUBS}

Shrubs listed at $45 \mathrm{c}$ each are $40 \mathrm{c}$ each for 10 or more

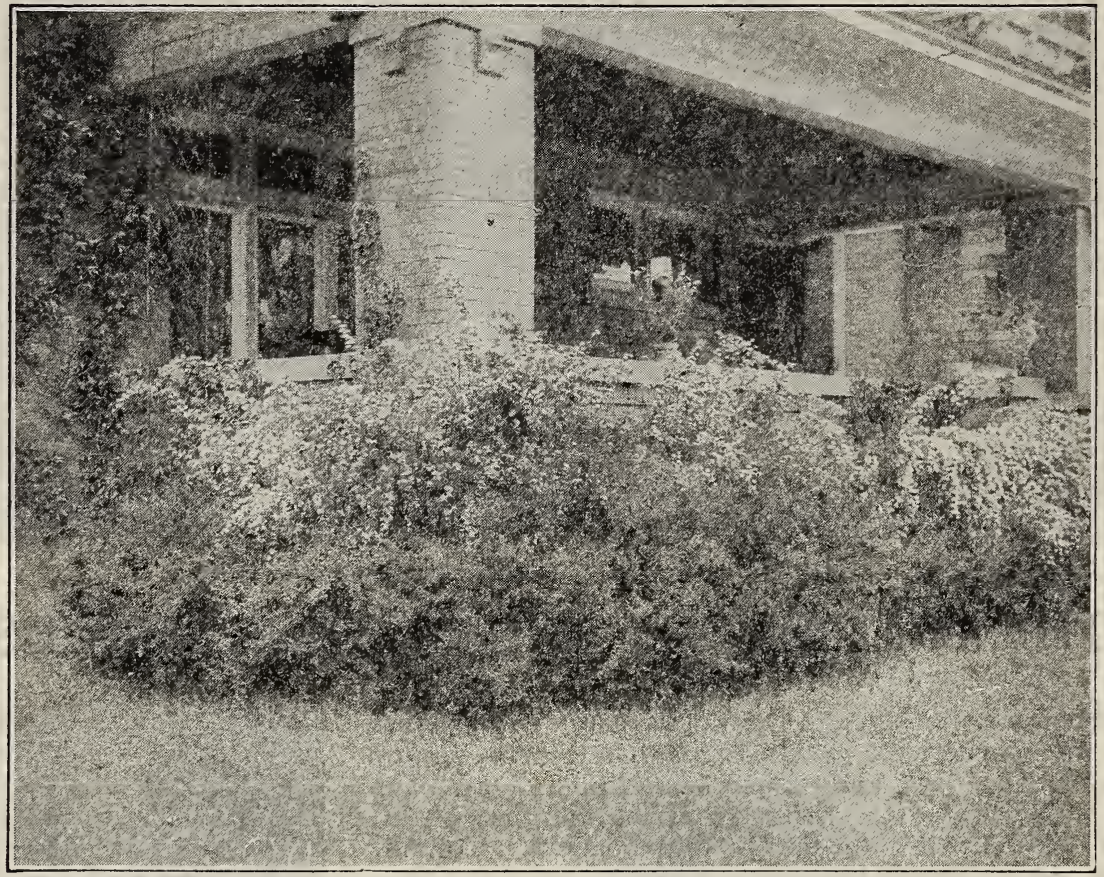

Barberry and Spirea Van Houtii

lthea-Grows 3 to $4 \mathrm{ft}$. A free flowering shrub, blooms in August and SepA tember; flowers resemble hollyhocks. A little tender here. 2 to $3 \mathrm{ft}$., $45 \mathrm{c}$ each. Colors: purple, white, rose, red, common red.

Almonds, Double White (Amygdalus Alba)-Grows 3 to $5 \mathrm{ft}$. White flowers like small roses; blooms early; decorative. 2 to $3 \mathrm{ft}$., $90 \mathrm{c}$ each.

Almonds; Double Pink (Amygdalus Rosea)-Same as above except flowers are pink. 2 to $3 \mathrm{ft}$., $90 \mathrm{c}$ each.

Aralia Pentephylla-Grows 4 to $6 \mathrm{ft}$. Valuable for its excellent heavy, bright foliage. Branches covered with short thorns. 2 to $3 \mathrm{ft} ., 45 \mathrm{c}$ each. 


\section{Flowering and
Deciduous SHRUBS}

\section{Shrubs listed at $45 \mathrm{c}$ each are $40 \mathrm{c}$ each for 10 or more}

Aralia Spinosa-Grows 6 to $8 \mathrm{ft}$. A strong, rapid growing, rugged shrub with large decidedly tropical looking leaves. Branches thickly covered with long spines. Flowers appear in large masses; white to yellow. A picturesque plant. 2 to $3 \mathrm{ft}$., $45 \mathrm{c}$ each.

Rerberis Thunbergi (Japanese Barberry)-The Barberry is used extensively where a good dwarf, bushy hedge is desired. Every branch is thickly studded with short thorns, and it is often purchased on this account. The foliage turns to a brilliant red in September, which is followed in the winter by a scarlet berry which helps to make it an attractive shrub the year round. It is not susceptible to wheat rust. 18 to 24 in., $35 \mathrm{c}$ each; $\$ 3.20$ per $10 ; 12$ to 18 in., 30c each; $\$ 2.80$ per 10. See page 17 for 100 lots.

Buckthorn (Rhamnus Frangula)-Grows 6 to $9 \mathrm{ft}$. A fine, vigorous shrub with dark green foliage; the white flowers are followed by small black berries. A good, hardy hedge plant; stands severe pruning. 2 to $3 \mathrm{ft}$., $45 \mathrm{c}$ each.

Calycanthus, Sweet Scented.-Grows 3 to $5 \mathrm{ft}$. The wood is fragrant, foliage rich; flowers are chocolate color, having a peculiarly agreeable odor. Blooms in June and at intervals afterwards. 2 to $3 \mathrm{ft}$., $45 \mathrm{c}$ each.

Cranberry High Bush (Viburnum Opulus)-Grows 6 to $8 \mathrm{ft}$. Foliage lustrous green, changing to rich copper; blossoms in May with clusters of flat-topped white flowers followed by scarlet berries. 3 to $4 \mathrm{ft} ., 45 \mathrm{c}$ each.

Currant (Ribes Aureum)-Grows 6 to $8 \mathrm{ft}$. The golden flowering currant; blooms in April and May, followed by large black berries; showy; thrives everywhere; red leaves in fall; excellent shrub for background. 2 to $3 \mathrm{ft}$., $45 \mathrm{c}$ each.

Deutzia Gracilis-Grows 1 to $2 \mathrm{ft}$. A dwarf growing compact variety; white flowers in May; good for border or foundation planting. Bushy grower. 12 to 18 in., $45 \mathrm{c}$ each.

Deutzia Crenata-Double white flowers; blooms in May and June. Attains a height of 2 to $4 \mathrm{ft}$. 12 to 18 in., $45 \mathrm{c}$ each.

Deutzia Lemoine-Grows 3 to $5 \mathrm{ft}$. Single white flowering, spreading habit, fine branches and leaves; blooms early in the summer. 18 to $24 \mathrm{in}$. plants, $45 \mathrm{c}$ each.

Deutzia (Pride of Rochester)-Grows 4 to $6 \mathrm{ft}$. Blooms early in the spring, with extra large white flowers; one of the hardiest of the Deutzia. 18 to 24 in. plants, $45 \mathrm{c}$ each.

Dogwood Red (Cornus Siberica)—Grows 6 to $10 \mathrm{ft}$. Dark green foliage, pale on the underside; blooms early in the summer with clusters of flat-topped, creamy white flowers, followed by light bluish fruit; branches are dark red; very attractive shrub. 2 to $3 \mathrm{ft}$., $45 \mathrm{c}$ each.

Dogwood Yellow (Cornus Lutea)-Grows 4 to $6 \mathrm{ft}$. A very pretty shrub for winter color effect; bark bright yellow, foliage a pea green. 2 to $3 \mathrm{ft}$. plants, $45 \mathrm{c}$ each.

Dogwood Gray (Cornus Panculata) Grows in a small tree of upright almost perfect habit. Foliage turns to crimson in fall. 2 to $3 \mathrm{ft}$., $45 \mathrm{c}$ each.

Flder Golden (Sambucus Aurea)-Grows 8 to $10 \mathrm{ft}$. A variety with golden yellow $\mathbf{L}$ foliage, vigorous and spreading grower; flowers white in flat-topped clusters, followed by reddish black berries; grows well on any soil; can be pruned into a neat, compact little bush; best of the golden foliage shrubs. 2 to $3 \mathrm{ft}$. plants, $45 \mathrm{c}$ each. 
Shrubs listed at $45 \mathrm{c}$ each are $40 \mathrm{c}$ each for 10 or more.

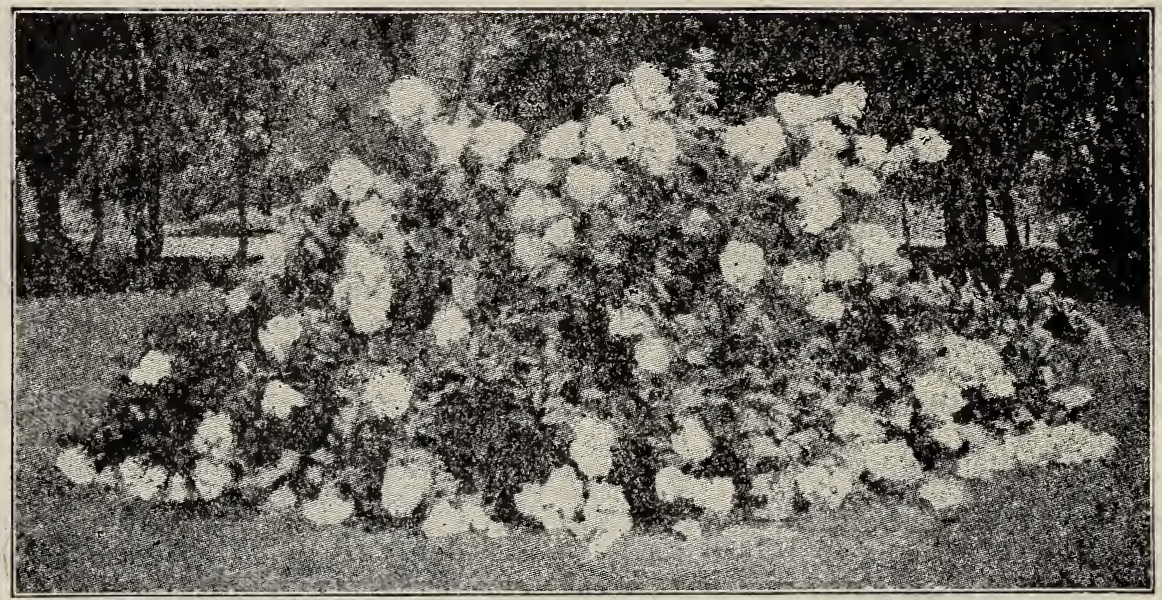

Hydrangia Planting

Golden Bell (Forsythea Fortunei)-Grows 4 to $6 \mathrm{ft}$. Has yellow, bell-shaped $\checkmark$ flower, in racemes, very early in the spring before the leaves are formed; upright in growth; yellow bark. 2 to 3 ft. plants, $45 \mathrm{c}$ each.

Golden Bell Weeping (Forsythea Suspensa)-Similar to above, but has long, drooping branches; very pretty shrub. 2 to $3 \mathrm{ft}$., plants, $45 \mathrm{c}$ each.

Hydrangia P. G. (Paniculata Grandiflora)-Grows 3 to $6 \mathrm{ft}$. This is one of the most valuable hardy shrubs; the flowers are borne in great pinnacles nearly a foot long, and changing from pure white to rose or bronze in late fall; blooms from August until frosts. 18 to 24 in. plants, $60 \mathrm{c}$ each.

Hydrangia Hills of Snow (Arborescens Sterillis)-Grows 3 to $5 \mathrm{ft}$. A new variety, much like the above, but commences to bloom in July and lasts until frost; flowers borne on long stems, and changing from pure white to green, a rare variety. 18 to 24 in. plants, $60 \mathrm{c}$ each.

Honeysuckle Tartarian (Lonicera T.)-Grows 6 to $8 \mathrm{ft}$. A very attractive, useful shrub, with abundance of fragrant flowers in the spring and bright red fruit in the fall. Somewhat spreading in growth. 2 to $3 \mathrm{ft}$., plants, $45 \mathrm{c}$ each.

Honeysuckle Morrowii (Lonicera M.)-Grows 6 to $8 \mathrm{ft}$. A Japanese variety, blossoms white, changing to yellow; refined foliage; long blooming period, followed by small berries, upright in growth. 2 to $3 \mathrm{ft}$. plants, $45 \mathrm{c}$ each.

Honeysuckle Fragrant (Lonicera F.) -Grows 4 to $6 \mathrm{ft}$. A very attractive shrub; foliage very pretty, with slender recurving branches. Flowers fragrant, needs protection in winter. 2 to $3 \mathrm{ft}$. plants, $50 \mathrm{c}$ each.

Kerria White (Rhodotypos Kerrioides)-Grows 3 to $5 \mathrm{ft}$. A very ornamental shrub with bright green foliage, and single flowers in May, followed by conspicuous shining black fruit in the fall. 2 to $3 \mathrm{ft}$. plants, $45 \mathrm{c}$ each.

Kerria Yellow (K. Japonica)-Grows 3 to $4 \mathrm{ft}$. Foliage deep green and very dense, branches vivid green and particularly showy in winter; flowers bright yellow. A very graceful shrub. 2 to $3 \mathrm{ft}$. plants, $45 \mathrm{c}$ each. 
Shrubs listed at $45 \mathrm{c}$ each are $40 \mathrm{c}$ each for 10 or more.

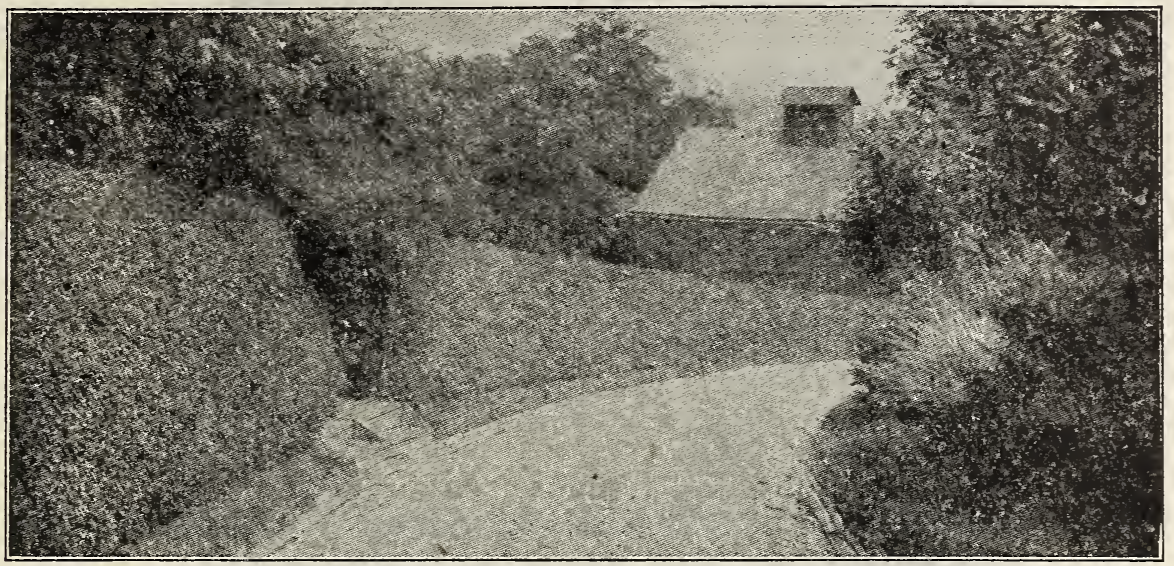

Privet Hedge

ilac Common Purple (Syringa Vulgaris)-Grows 6 to $8 \mathrm{ft}$. One of the best old 4 time garden shrubs; bluish purple flowers. 2 to $3 \mathrm{ft}$. plants, $45 \mathrm{c}$ each.

Lilac White (Syringa Vulgaris Alba)-Same as above, except white bloom. 2 to $3 \mathrm{ft}$. plants, $45 \mathrm{c}$ each.

Lilac Persian-Grows 5 to $6 \mathrm{ft}$. Light blue flowers, narrow leaves growing on slender branches; finer variety than the above. 2 to $3 \mathrm{ft}$. plants, $45 \mathrm{c}$ each.

Pepper Bush (Clethra Alifolia)-Grows 3 to $4 \mathrm{ft}$. A handsome little shrub, delightfully fragrant in September when covered with long, showy wands of white flowers; foliage very dark green. 18 to 24 in. plants, $45 \mathrm{c}$ each.

Pea Tree' (Caragana Arborescens)-Grows 8 to $10 \mathrm{ft}$. A very pretty dwarf tree or shrub, with yellow pea-shaped flowers in May, foliage in light green; very small and fine. 2 to $3 \mathrm{ft}$. plants, $45 \mathrm{c}$ each.

Privet Amoor River (Ligustrum Amurense)-Grows 5 to $8 \mathrm{ft}$. Will stand 50 degrees below zero; valuable shrub for hedges and grouping with other shrubs; upright in growth; foliage, glossy green. 2 to $3 \mathrm{ft}$. plants, $30 \mathrm{c}$ each; $\$ 2.50$ per 10; 18 to 24 in. plants, $25 \mathrm{c}$ each; $\$ 2.00$ per 10 . For 100 rates, see page 17.

Privet Ibota (Ligustrum I.)-Grows 5 to $7 \mathrm{ft}$. Very much like the above, and just as hardy, but more spreading in growth; foliage, grayish green, and covered with black berries in the fall. 2 to $3 \mathrm{ft}$. plants; $30 \mathrm{c}$ each; $\$ 2.50$ per 10 .

Ouince Japan (Cydonia Japonica)-Grows 3 to $4 \mathrm{ft}$. Very early; in the spring this shrub is covered with dazzling scarlet flowers, followed by small quinceshaped fruit, which are fragrant; grows bushy and dense with protecting thorns. 18 to 24 in. plants, $45 \mathrm{c}$ each.

Rose Multiflora-This rose is of climbing habit; but is used much in shrubbery planting, as it will form a medium sized bush; covered with pink and red roses during June and July. Foliage pretty. 2 year plants, $45 \mathrm{c}$ each.

Rose Madam Planter-Very much like the above, but not a climber; good for shrubbery planting or rose hedge; flowers white. 2 year plants, $45 \mathrm{c}$ each. 
Shrubs listed at $45 \mathrm{c}$ each are $40 \mathrm{c}$ each for 10 or more.

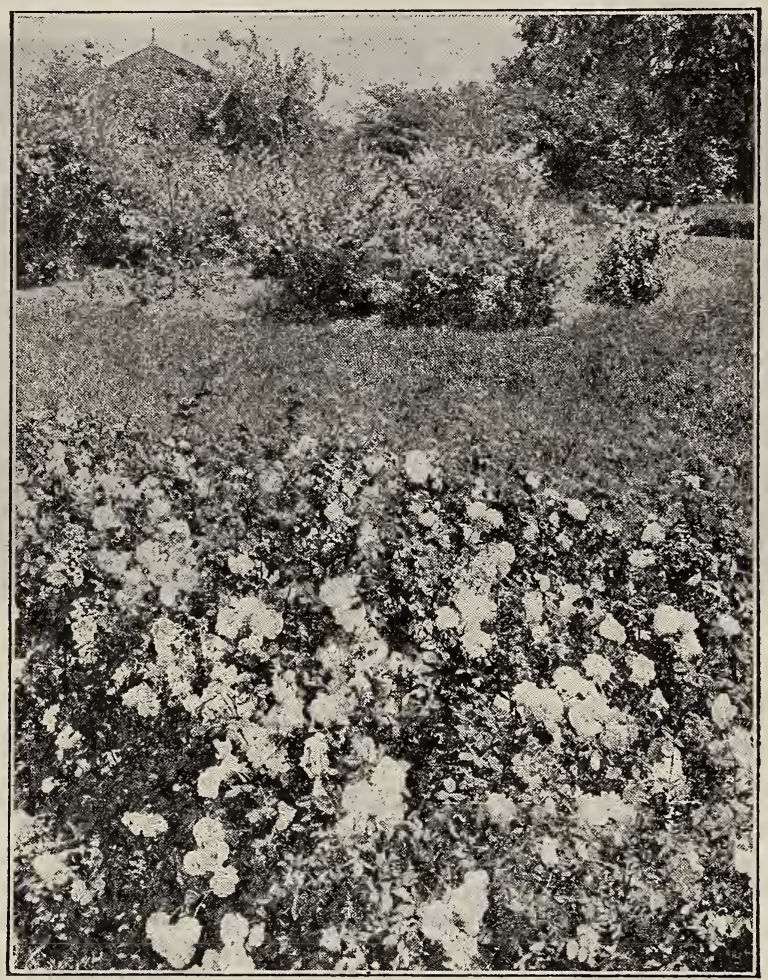

Madam Planter Roses

Rose Rugosa-3 to $5 \mathrm{ft}$. This rose is very popular; used as a shrub it is fine; the foliage is refined and charming all summer; blossoms large, single, producet throughout the summer, followed by crimson fruits. Very hardy; red flowers. $45 \mathrm{c}$ each.

Sumac Cut Leaf (Rhus Typhina)-Grows 6 to $10 \mathrm{ft}$. A very striking plant of $\boldsymbol{S}$ moderate size, with deeply cut leaves resembling fern leaves; dark green, turning to rich red in fall; red, impressive fruit in fall and winter. 2 to $3 \mathrm{ft}$., $45 \mathrm{c}$ each.

Sumac Smooth (Rhus Glabra)-Grows 5 to $8 \mathrm{ft}$. Beautiful leaves which color brightly in the fall; flowers in July, followed by crimson or bronze fruit. 3 to $4 \mathrm{f}$. plants, $45 \mathrm{c}$ each.

Snowball (Viburnum Sterilis)-Grows 6 to $8 \mathrm{ft}$. The common snowball, which blooms the last of May, with lovely white balls of flowers. 2 to $3 \mathrm{ft}$. plants, $45 \mathrm{c}$ each.

Syringa (Mock Orange)-Grows 6 to $8 \mathrm{ft}$. Vigorous habit, very hardy, with large, handsome foliage, and fragrant white flowers in June. 2 to $3 \mathrm{ft}$. plants, $45 \mathrm{c}$ each.

Strawberry Tree (Euonymus Europaeus)-Grows 5 to $7 \mathrm{ft}$. One of the finest varieties grown; bark, light green; foliage changes to brilliant colors in fall; spreading in growth. A fine shrub. 2 to $3 \mathrm{ft}$., $45 \mathrm{c}$ each. 


\section{Flowering and
Deciduous SHRUBS}

Shrubs listed at $45 \mathrm{c}$ each are $40 \mathrm{c}$ each for 10 or more.

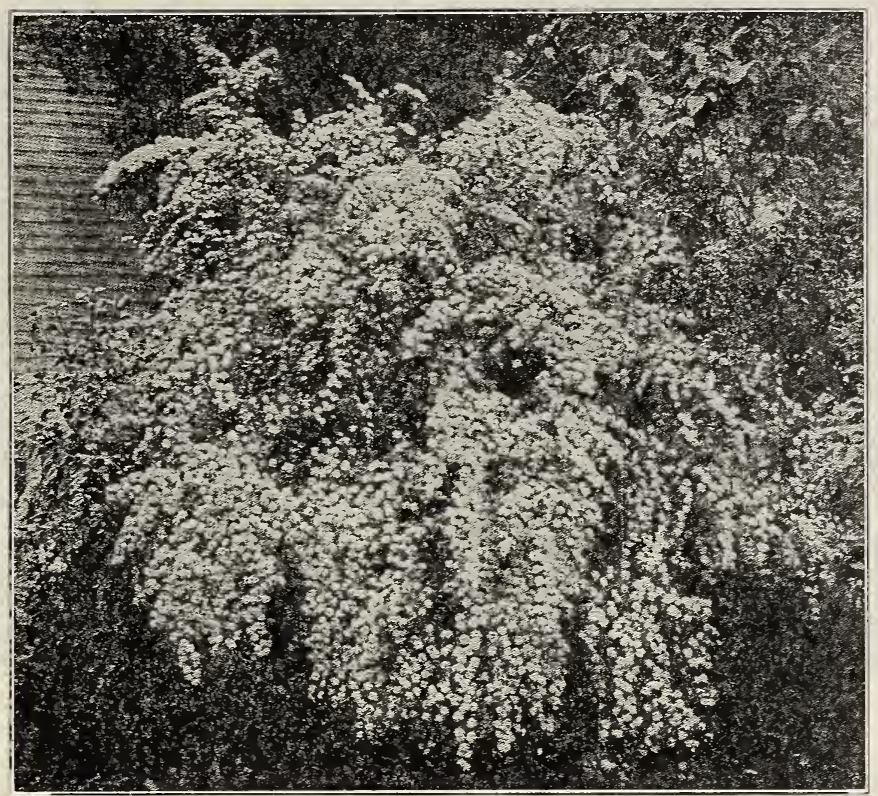

Spirea Van Houtei

Snowberry White (Symphoricarpus Racemosus)-Grows 3 to $5 \mathrm{ft}$. Very small $\boldsymbol{S}$ rose colored, flowers in June, followed by clusters of milk white berries which remain far into the winter; very pretty winter shrub. 2 to $3 \mathrm{ft}$. plants, $45 \mathrm{c}$ each.

Snowberry Red (Symphoricarpus Vulgaris)-Grows 3 to $5 \mathrm{ft}$. Very much like above, but the berries are red and smaller; sometimes called Indian currant or coral berry. 2 to $3 \mathrm{ft}$. plants, $45 \mathrm{c}$ each.

Spirea Van Houtei (Bridal Wreath)-Grows 4 to $6 \mathrm{ft}$. One of the most beautiful and common shrubs; an immense bloomer. Pure white flowers early in the summer. 3 to $4 \mathrm{ft}$. plants, $45 \mathrm{c}$ each. See page 19 for other sizes.

Spirea Ballardii-Grows 4 to $5 \mathrm{ft}$. Pink flowers, in large spikes; upright in habit, with red brown branches, dull green foliage. 2 to $3 \mathrm{ft}$. plants, $45 \mathrm{c}$ each.

Spirea Ballardii Alba-Same as the above, but the bloom is white. 2 to $3 \mathrm{ft}$. plants, 45c each.

Spirea Anthony Waterer-Grows 2 to $3 \mathrm{ft}$. Dwarf. Flowers, bright crimson; free bloomer, best late in the summer; flowers in round, flat-topped clusters; foliage, light green. 12 to 18 in. plants, $45 \mathrm{c}$ each.

Spirea Collosa Rubra-Grows 1 to $2 \mathrm{ft}$. Much like the above but smaller grower; crimson flowers. 12 to 18 in. plants, $45 \mathrm{c}$ each.

Spirea Collosa Alba-Grows 1 to $2 \mathrm{ft}$. White flowers in large, flat-topped clusters; blooms most all summer. 12 to 18 in. plants, $45 \mathrm{c}$ each.

Spirea Golden (Opulifolia Aurea)-Grows 5 to $8 \mathrm{ft}$. Upright habit; white, heavy flowers umbels in June; old flowers turn to dark red or brown; young foliage, light yellow, turning to dark red or bronze in fall. 3 to $4 \mathrm{ft}$. plants, $45 \mathrm{c}$ each. 
Shrubs listed at $45 \mathrm{c}$ each are $40 \mathrm{c}$ each for 10 or more.

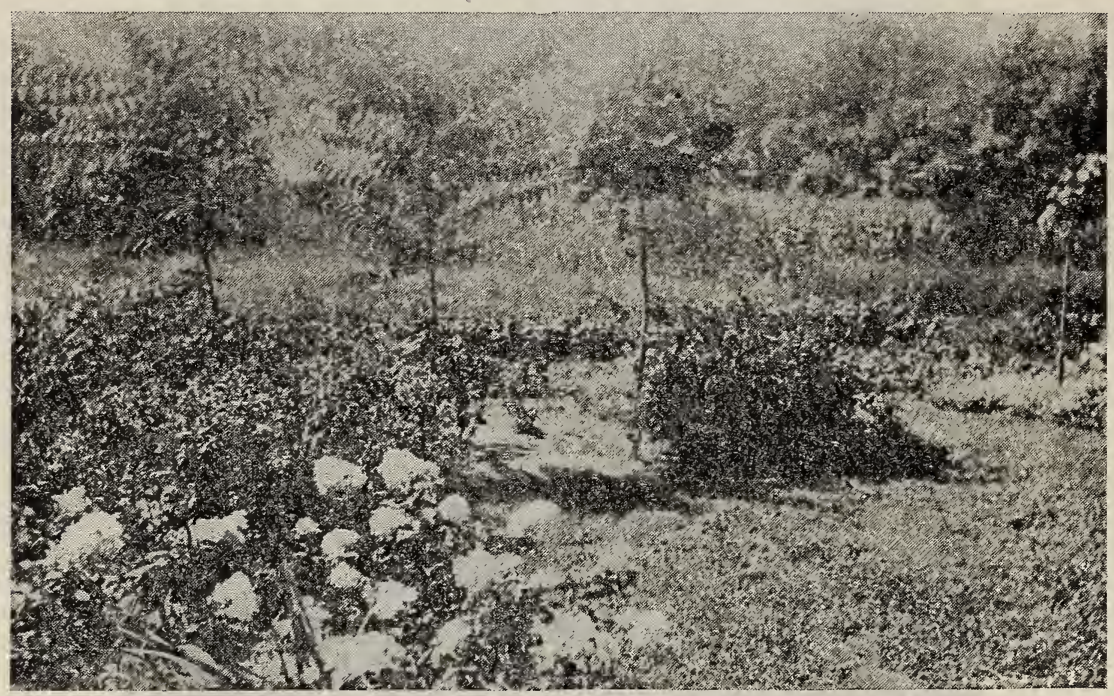

Shrubhery Furnished by Us (first year)

Spirea Thunbergii-Grows $3 \mathrm{ft}$. Fine, slender leaves and branches, with its profuse blossoms in May, makes it especially valuable for planting at the base of taller shrubs. 12 to 18 in. plants, $45 \mathrm{c}$ each.

Spirea Froebella-Grows $3 \frac{1}{2}$ to $4 \mathrm{ft}$. Upright branches; deep green foliage, which is bright red when young. Flowers in flat clusters, good in masses. 18 to 24 in. $45 \mathrm{c}$ each.

Tamarix Afriacan-Grows 4 to $6 \mathrm{ft}$. Fine, feathery, green foliage; pinkish white

blooms in June; very picturesque plant. If cut back each year, will make much nicer foliage. 2 to $3 \mathrm{ft}$. plants, $45 \mathrm{c}$ each.

Tamarix Blue (Glauca)-Very much like the above, but the foliage is a delicate misty blue color. 2 to $3 \mathrm{ft}$. plants, $45 \mathrm{c}$ each.

Tree of Heaven (Ailanthus) -10 to $15 \mathrm{ft}$. More of a tree than a shrub, but when cut back each year makes a very desirable shrub. Hard and very rapid grower. Tropical foliage, long, fern-like leaves; good for background of other shrubs. 3 to $4 \mathrm{ft}$. plants, $45 \mathrm{c}$ each.

Weigelia Eva Rathke-Grows 3 to $4 \mathrm{ft}$. The most distinct and one of the most

attractive varieties. Flowers deep carmine red. 18 to 24 in. plants, $60 \mathrm{c}$ each.

Weigelia Rosea-4 to $6 \mathrm{ft}$. A tall growing variety with deep pink flowers in great profusion during June, and at intervals through the summer. 2 to $3 \mathrm{ft}$., $50 \mathrm{c}$ each.

Weigelia Variegated-Grows 3 to $4 \mathrm{ft}$. Dwarf. Leaves have a creamy white margin, flowers pink; much used for contrastive purposes. 18 to 24 in. plants, $45 \mathrm{c}$.

\section{SPECIALS}

We offer smaller sized plants in the following three popular shrubs:

Barberry Thunbergii-8 to 10 in., $10 \mathrm{c}$ each.

Spirea V. H. Bridal Wreath-12 to 16 in., $10 \mathrm{c}$ each.

Privet Amoor River-12 to 16 in., 10c each. 


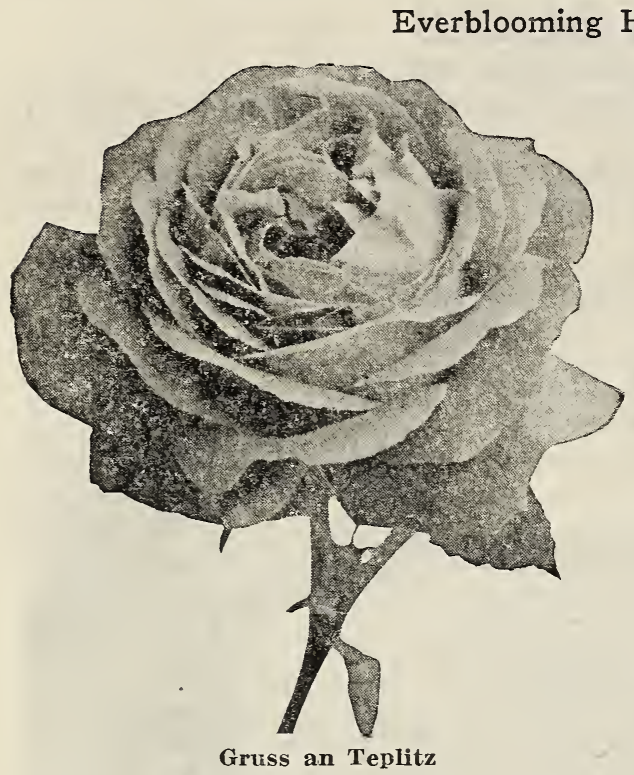

Large two-year, field grown bushes, $75 \mathrm{c}$ each. These Roses will bloom the first year with proper care.

Gen. Jacqueminot-One of the most popular of the red roses, brilliant crimson, large bloom, fragrant and hardy.

Magna Charta-A general favorite, prized on account of its strong, upright growth and bright, healthy foliage, as well as for its magnificent bloom. The color is a beautiful bright pink.

Paul Neyron-Deep, shining rose, very fresh and pretty. Flowers large, often measuring five inches in diameter. The buds always develop fine, perfect roses.

American Beauty-A hardy rose, of the largest size, having the ever-blooming qualities of the tea roses; it is the sweetest of all roses; the color is a deep, brilliant red, shaded to a rich carmine.

Gruss an Teplitz-Color a rich scarlet, shading to velvety crimson; very fragrant; a free, strong grower, and the most profuse bloomer known to us, being covered with flowers the whole season. The foliage is extremely beautiful, all the younger growth being a bronzy plum color.

Frau Karl Druschki-A pure, paper-white, large sized and free flowering. The bloom is perfect in form on fine, long stems.

Prince de Rohan--Very dark, velvety crimson. A prolific bloomer and flowers are of excellent form and size.

Soleil di Or-A fine, hardy out door rose, especially valuable because of its rare color; gold and orange yellow, varying to ruddy gold, suffused with nasturtium red.

Baby Rambler-The original dwarf form of crimson rambler. The wonderful persistency of its bloom makes it one of the choicest plants in cultivation for summer bedding, and as an edging to borders of shrubs, roses or perennials, it has no equal.

Mrs. John Laing-Soft pink; large and of fine form, produced on strong stems; exceedingly fragrant. An exceptionally handsome and free-blooming rose of vigorous growth and fine habit.

June Rose-Double pink, very hardy; makes large bush. Profuse bloomer early in summer. $45 \mathrm{c}$ each.

Persian Yellow-An old favorite; very early, fragrant, shrubby type for the yard. Deep golden yellow.

Lady Hillington-Pale yellow, half tea rose, produces almost perfect buds.

Coquetie des Alps-White, tinged with carmine, very fine, and free bloomer. hardy.

Coquette des Blanch-White, medium size, very double, free bloomer and

\section{ROSES}

To obtain the best results Roses should be planted in beds, and in the winter cut off six inches above the ground and covered with about six to eight inches of leaves, this to be taken off in the spring, and the bed fertilized and well cultivated.

Rugosa-Japanese Rose. See page 22. 


\section{CLIMBING ROSES}

Large two-year, field grown vines, 60c each

Climbing American Beauty-Much like the bush form of this name except it has the climbing habit.

Excelsa (Red Dorothy Perkins)-A radiant, blood-red cluster rose. The clusters are very large and fairly cover the vines. It is best to plant this variety where crimson rambler is not hardy.

The Illinois Rose (Rosa Setigera)-Large single, pink, blossoms in July; beautiful foliage, absolutely hardy. The stems turn red in winter, which together with quantities of crimson fruits, produce a charming winter effect.

Crimson Rambler-It is a vigorous grower; flowers glowing and productive in immense panicles.

Climbing Gruss an Teplitz-An exact counterpart of the bush Rose Gruss an Teplitz. Color, velvety crimson.

Dorothy Perkins-Beautiful shell pink, full and double; large size for a cluster rose; it is a hardy, strong grower.

Prairie Queen-The flowers are very large and of peculiar globular form; bright, rosy red; changing to lighter as the flower opens. Of strong, rapid growth.

Thousand Beauties (Tausendschon)-Colors of every imaginable shade, from pure white to deep pink. Almost thornless.

Multiflora Rose-Double, pink; strong grower; very hardy, profuse bloomer.

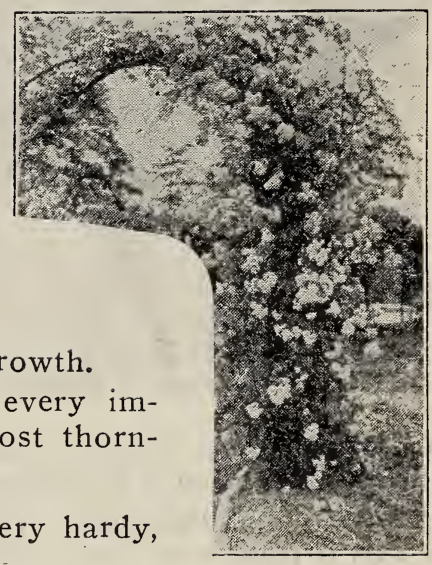

\section{CLIMBING VINES}

Illinois Rose

Strong two-year, $35 \mathrm{c}$ each

Honeysuckle, Scarlet Trumpet-One of the handsomest in cultivation; coral flowers; very vigorous and hardy; blooming all summer.

Trumpet Vine (Tecoma Radicans)-Handsome, dark green foliage and showy clusters of orange and scarlet flowers during the summer.

Bittersweet-A native vine that is especially ornamental in fall and winter, with brilliant orange and scarlet fruit.

Chinese Matrimony Vine-A strong, hardy climbing vine. Bright, rosy-purple flowers, followed by brilliant scarlet berries.

Wisteria (Purple) - One of the finest climbers, of rapid growth, and perfectly hardy, with long, pendulous clusters of bluish purple. Flowers in June.

Engleman's Ivy-It is one of the finest ivies we have. The brilliant coloring of the leaves in autumn, together with perfect hardiness, makes it a valuable climber for covering brick or stone walls. Where hardiness is necessary, the Englemani will be found much superior to Boston ivy.

American Ivy-The well known native vine with the five parted leaves, that change to rich crimson in autumn; berries blue black; very rapid grower and perfectly hardy.

\section{CLEMATIS}

\section{2 years}

Jackmanii-A very profuse blooming variety, with flowers from four to six inches in diameter; of an intense violet purple color, borne successionally in continuous masses on the summer shoot. $75 \mathrm{c}$ each.

Henryii-Large, pure white flowering. $75 \mathrm{c}$ each.

Paniculata-New. A strong, vigorous grower; very free flowering; pure white; unusually fragrant. 50c each. 


\section{Gardy ELOWERS}

\section{PERENNIALS}

Chrysanthemum (hardy)-They make a brilliant show in September and October. Colors, white and yellow and pink. 20c each; 3 for 50c.

Golden Rod (Canadian)-The spray of perennial gold terminating with each year's growth, is on stems 3 to 5 feet high. September to October. 15c, two for $25 \mathrm{c}$.

Golden Glow-Flowers are produced on long stems in large quantities, and resemble golden cactus dalies. $15 \mathrm{c}$ each.

Hibiscus "Meehan's Mallow Marvels"-A magnificent new strain of hardy mallows, which for size and profusion of bloom and richness of coloring are among the most striking and beautiful perennials that grow. Flowers 8 to 10 inches in diameter; color, red and white and pink. $35 \mathrm{c}$ each.

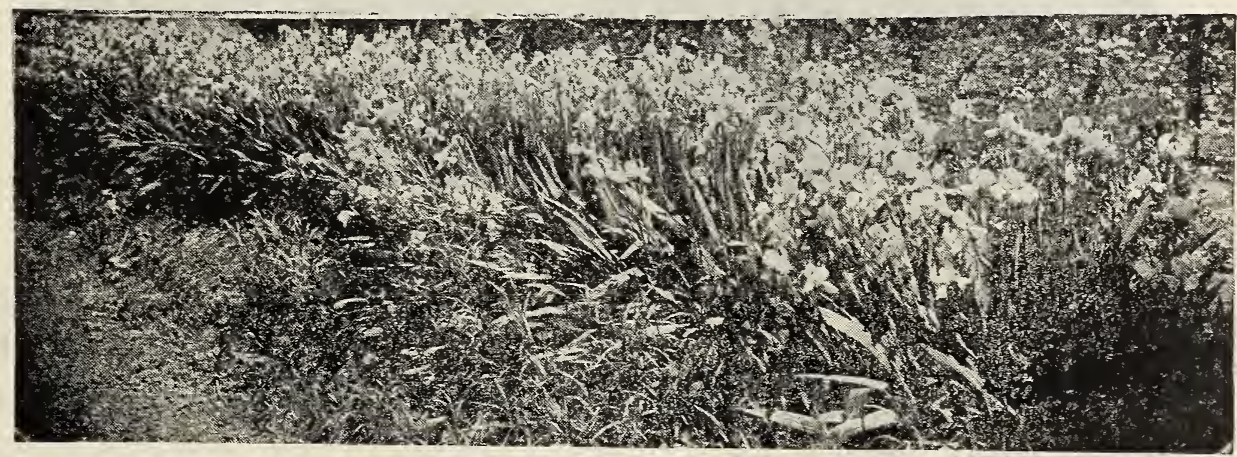

Iris Planting

\section{SIBERIAN IRIS}

$15 \mathrm{c}$ each; $\$ 1.50$ per 12

Dwarf Blue grows about 6 in. Gertrude Blue grows 1 to $2 \mathrm{ft}$. Florentinea White grows $2 \mathrm{ft}$. Parisiensis Purple grows $1 \frac{11 / 2}{2}$ to $2 \mathrm{ft}$. Aurea Yellow grows $2 \mathrm{ft}$.

Japanese Iris grows 2 to $3 \mathrm{ft}$; blooms in June and July; flowers very large. 30c each. $\$ 3.00$ per 12 . Following colors: cream, purple with gold, white, purple, blue.

Lily of the Valley-Small, white flowers, very fragrant. 10c each; 70c per 12.

Lily Day-Yellow. Each, 10c; 12 for $\$ 1.00$.

DesModium Penduliflorum-A shapely, pretty leaved semi-herbaceous shrub from 2 to 4 feet high; literally covered in early autumn with long, drooping racemes of magenta flowers. $50 \mathrm{c} ; \$ 4.50$ per 10.

Bleeding Heart-Charming hardy perennial plant with much cut foliage. Flowers of interesting structure. One of the choicest members of old-fashioned gardens. 50c each; $\$ 5.00$ per 12.

Digitalis (Foxglove)-Blooms from July to August. Height about $3 \mathrm{ft}$. Colors mixed. This is an old favorite and very well known. 25c each; $\$ 2.50$ per 12 .

Sweet William-Blooms May to July. Height about 12 in. Colors in assortment. These can be planted in masses or with shrubbery. $25 \mathrm{c}$ each; $\$ 2.50$ per 12 . 


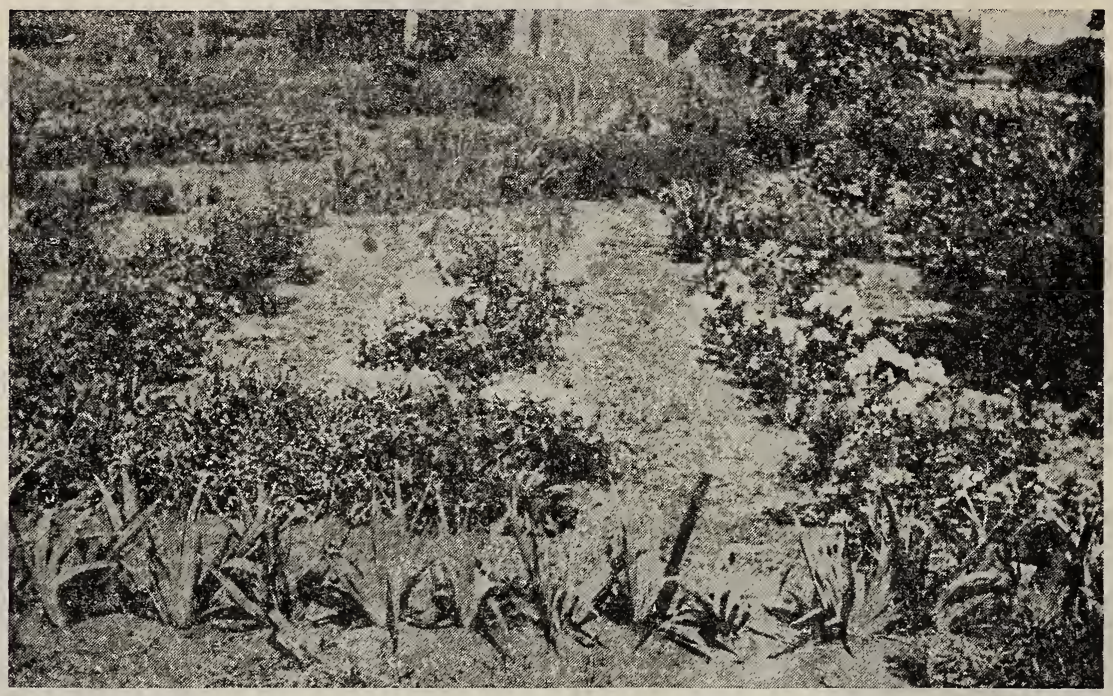

Hardy' Perennials Planted in the Nursery

Blazing Star (Liatris Pycnostachya)-Grows 3 to $4 \mathrm{ft}$. Showy purple flowers in long spikes, which are very effective among other perennials or shrubs; foliage grass like; blooms in August and September. 15c each; $\$ 1.50$ per 12.

Delphinium (Larkspur)-Blooms July to Augus.t. Height about $3 \mathrm{ft}$. Colors mixed. Flowers on long spikes. $25 \mathrm{c}$ each; $\$ 2.50$ per 12.

Oriental Poppy-Blooms June and July. Height 2 to $3 \mathrm{ft}$. Scarlet flowers with a black center spot. Great favorite. $25 \mathrm{c}$ each; $\$ 2.50$ per 12 .

Coreopsis Lanceolata Grandiflora-The perfected strain of a long popular hardy plant. Flowers are rich golden yellow, borne in great profusion nearly the entire summer. $15 \mathrm{c}$ each; $\$ 1.50$ per dozen.

Gaillardia Grandiflora Superba (Blanket Flower)-Makes one of the most gorgeous and prodigal displays of all perennials. Flowers often measure 3 inches in diameter, on clean 2 feet stems. A hard center of deep maroon is thickly bordered by petals of orang,e and yellow, ringed by circles of crimson, red and maroon. $15 \mathrm{c} ; \$ 1.50$ per dozen.

Eupatorium-Coelestinum. All-covering cymes of pretty blue Ageratum-like flowers. 2 feet. $15 \mathrm{c} ; \$ 1.50$ per dozen.

Yacca-A tropical-looking plant, with long, narrow leaves; the flower stalks rise from the center about three feet high, and are covered with creamy, white bell-shaped flowers, forming a perfect pyramid; perfectly hardy, the leaves staying green all winter. Strong, two-year plants. $25 \mathrm{c}$ each.

Butterfly Bush (Buddleya Variabilis Magnifica)-Ever-blooming. This shrub from a young plant set out in the spring will mature to full size the first summer, making a handsome bush. It produces long, graceful stems, which terminate in tapering pinnacles of beautiful lilac colored flowers. Strong field grown plants. $50 \mathrm{c}$ each.

Grass Ribbon-Grows 1 to $1 \frac{1}{2} \mathrm{ft}$. Variegated foliage; excellent for bordering large beds. $15 \mathrm{c}$ each; $\$ 1.50$ per 12 .

Shasta Daisy-American Legion flower, therefore every one should have this flower in their garden. Flowers large snowy white, often four inches across, in bloom all summer. Strong plants.

$25 \mathrm{c}$ each; 2.50 per 12 , except noted 


\section{$\underset{\substack{\text { Hardy } \\ \text { Garden }}}{\text { FLOUERS }}$}

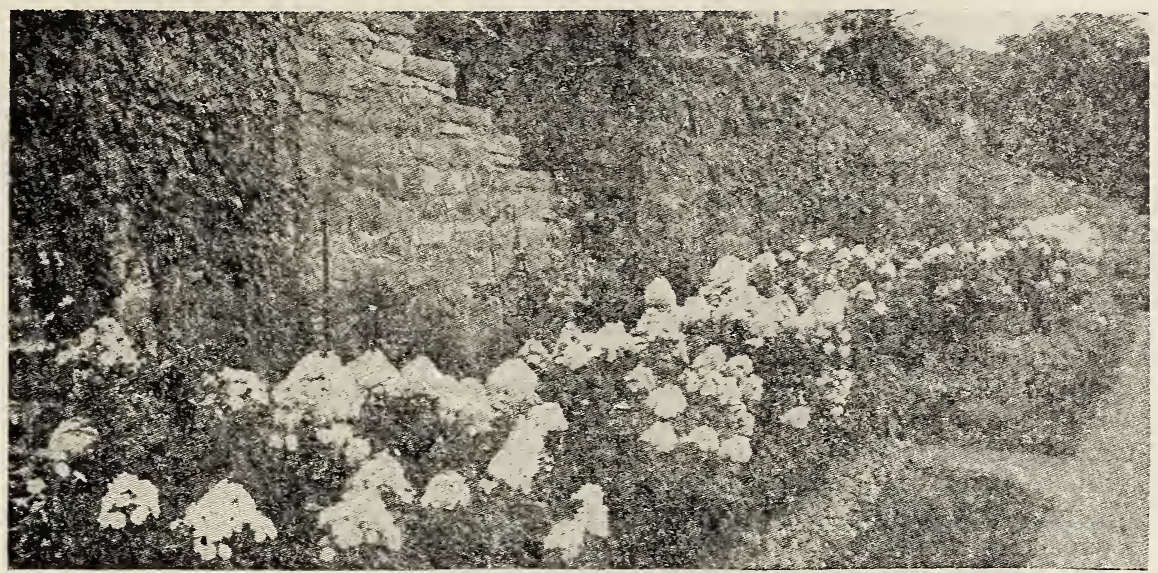

Hardy Phlox Planting

\section{HARDY PHLOX}

25 c each; $\$ 2.50$ per 12 , except noted

The finest and most useful of the herbaceous plants. They succeed in almost any soil, or any position. Flowers throughout a long season.

Miss Lingard-Longest spikes of any Phlox; blooms from the ground up. Waxy white, lavender eye.

R. P. Struthers-Rosy carmine with claret-red eye.

Ryndstrom-Color a lively shade of rose-pink, much like Paul Neyron Rose; flowers very large.

Unnamed Phlox-20c each; $\$ 2.00$ per 12. Pink, purple and white.

\section{HARDY ASTERS}

Beauty of Colwell-One of the best; in its prime during September when the 3 to 4 foot, branchy plants are literally covered with semi-double flowers of Ageratum-blue. 20c; $\$ 2.00$ per dozen.

St. Egwin-Plant is dense, bushy, about 30 inches high, with very ornamental fine cut, dark green foliage. Unlike most top blooming sorts, this variety blooms profusely clear up from the ground; delicate pastel pink. 20c each; $\$ 2.00$ per dozen.

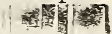

Acris-Summer flowering, very rich with violet-blue flowers during July and August; 12 to 15 inches. 20 c each; $\$ 2.00$ per 12 .

\section{PAEONIES}

Two year roots, and Choice List of Varieties

Festiva Maxima-Large, full double bloom, pure white, strong grower, one of the best whites. 50c each.

L'Esperence-Rose pink, good size and form; fragrant flower. One of the earliest, strong and vigorous, excellent cut flower. $45 \mathrm{c}$ each.

Gen. Bertrand-Late pink, large flower, good bloomer; excellent late kind. $45 \mathrm{c}$ each.

Felix Crouse-Late; large round heads perfectly double; deep crimson marked with cardinal at base of petals, a very choice variety. $75 \mathrm{c}$ each.

Rubra Superba-Large, compact, deep rose carmine or crimson, fragrant, very late, and considered one of the best late varieties. $60 \mathrm{c}$ each. 


\section{CANNAS}

Strong bulbs, 15c each; $\$ 1.50$ per 12

Of rapid growth and tropical appearance throughout the summer. They present a mass of gorgeous colors. The following varieties are among the best. Good quality bulbs.

King Humbert-4 ft. Bronze leaves. Flowers scarlet color, very large. The best of the bronze leaved varieties.

Florence Vaughn-3 ft. Green foliage. Flowers rich golden yellow, spotted with bright red. Extra good bloomer.

Hungaria-31 $/ 2 \mathrm{ft}$. Very compact, almost dwarf. Leaves bluish green; flowers very large; color pale pink with satin sheen.

Orange Bedder $-4 \mathrm{ft}$. Green foliage; orange color, with just enough scarlet suffusion to intensify the dazzling mass of color; free bloomer.

Maros-3 ft. Pure white flowers; free bloomer.

Rosea Gigantea-Tall growing; bronze leaved; bright red bloom. One of the best of the tall growing. $6 \mathrm{ft}$.

\section{DAHLIAS}

Strong field grown divisions. 20c each; $\$ 2.00$ per 12

Should be planted last of April

Electric-Tall growing; yellow, very fine.

Apple Blossom-Decorative; a wonderful pink shade, large.

Dark Beauty-An excellent red variety.

Zulu-Lovely dark maroon; decorative.

\section{GLADIOLIS}

$10 \mathrm{c}$ each; $\$ 1.00$ per 12 . Good choice bulbs.

America-Soft pink, most popular.

Mrs. Francis King-Light scarlet, large wide open flowers.

York White-White, with slight touch of violet.

Panama-Clear pink, large flowers, set well on the stem.

Schwaben-Canary yellow, an old favorite, sturdy plant.

War-Blood red, large flowers, free bloomer; late.

Baron Hulot-Rich deep indigo blue, only blue variety known; very fine sort. per 12 .

Phillips Mixture-A good mixture of all the colors we have in Gladiolis. 90c

\section{LAWN GRASS SEED}

Blue Grass-50 cents per pound, sent prepaid. Sow one pound for three square rods. This is the best lawn grass; sow in April and rake in well.

\section{SUDAN GRASS}

20c per lb. 6 lbs. \$1.00.; 10 lbs. or more, 10c per lb.

Excellent annual for hay or pasture, and a fine dry weather grass; sow broadcast about $20 \mathrm{lbs}$. per acre. 


\section{Descriptions of these items will be found in catalogue}

All the following items can be sent by parcel post, and if you wish your order or any part of your order sent this way, use these prices, otherwise we will ship by Express or Freight.

THESE PRICES ARE ALL PREPAID, no postage is necessary.

\section{APPLES}

3 to $4 \mathrm{ft} .35 \mathrm{cts}$. each; 6 or more $32 \mathrm{cts}$. each.

Varieties. Delicious, Stayman's Winesap, Baldwin, Grimes Golden, Jonathan, M. B. Twig, Gano, Winesap, Greening, Wealthy, Ea Harvest, Red June, Dyer, Benonia, Russett, Hyslop Crab.

3 to $4 \mathrm{ft}$.

\section{PEACHES}

Varieties. Elberta, J. H. Hale, Champion, Crosby, Greensboro, Lovell Seedling.

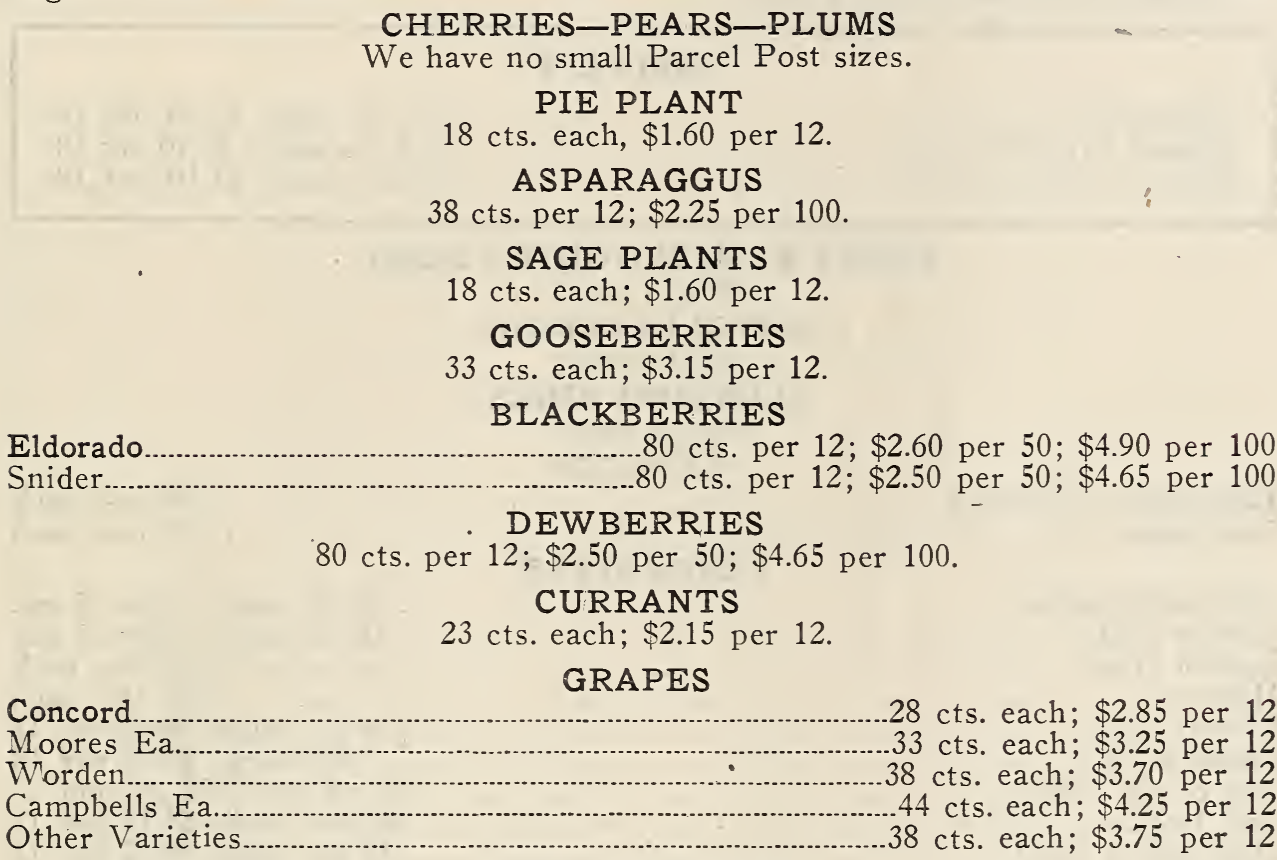

\section{STRAWBERRIES}

Senator Dunlap.............................................. 25 plants 38 cts.; 50 plants 70 cts.;

Gandy.... 100 plants $\$ 1.10 ; 500$ plants $\$ 5.15$. .25 plants 65 cts.; 50 plants $\$ 1.05 ; 100$ plants $\$ 2.15$

Progressive Everbearing.

25 plants 80 cts.; 50 plants $\$ 1.30 ; 100$ plants $\$ 2.45$ $\$ 1.35$ per $50 ; \$ 2.65$ per 100 . 55 cts. per $12 ; 80$ cts. per 25 ;

\section{RASPBERRIES}

Columbia or Royal Purple.. $\$ 2.65$ per $50 ; \$ 4.25$ per 100 . 2 year plants Royal Purple......................... $\$ 1.05$ per $12 ; \$ 2.05$ per 25; Other Varieties $\$ 3.15$ per $50 ; \$ 6.25$ per 100 . 80 cts. per $12 ; \$ 1.60$ per 25 ; 2 year in Cumberland. 80 c per $12 ; \$ 2.60$ per $50 ; \$ 5.25$ per 100 


\section{(Prices are post paid.) \\ EVERGREEN AND ORNAMENTAL TREES \\ Cannot be sent by parcel post.}

HEDGE PLANTS

Barberry.

18-24 in. 38 cts. each; $\$ 3.35$ per 10

Barberry

$12-18$ in. 33 cts. each; $\$ 2.90$ per 10

Privet Amoors.

2 to $3 \mathrm{ft} .33$ cts. each; $\$ 2.65$ per 10

Privet Amoors

18 to 24 in 28 cts. each; $\$ 2.21$ per 10

Privet Ibota.

Arbor Vitea.

2 to $3 \mathrm{ft} .33 \mathrm{cts}$. each; $\$ 2.65$ per 10

Spirea Van Houtei

Spirea Van Houtei.

12 to 18 in. 43 cts. each; $\$ 3.65$ per 10 2 to $3 \mathrm{ft} .38 \mathrm{cts}$. each; $\$ 3.20$ per 10

SHRUBS

All varieties.

$.50 \mathrm{cts}$ each; $\$ 4.30$ per 10 except following

Almonds, Pink and White.

96 cts. each

Hydrangia P. G.

65 cts. each

Hydrangia Hills of Snow..

65 cts. each

Privet see under Hedge Plants.

SPECIALS

Barberry.

Special Bridal Wreath

Privet.

15 cts each; $\$ 1.10$ per 10

15 cts. each; $\$ 1.10$ per 10

15 cts. each; $\$ 1.10$ per 10

\section{ROSES EVERBLOOMING BUSH \\ 80 cts. each. \\ ROSES CLIMBING \\ 68 cts. each. \\ CLIMBING VINES \\ 43 cts. each. \\ CLEMATIS}

Jackmanii or Henryi

83 cts. each

Panculata.

\section{PERENNIALS}

Chrysanthemums.

Golden Rod..

Golden Glow..

Hibiscus.

Liberty Iris.

Japanese Iris

Lily of the Valley

Lily Day.

Desmodium Pend.

Bleeding Heart..

Digitalis.

Sweet William

Blazing Star

Delphinium.

Oriental Poppy.

Shasta Daisy.

Coreopsis.

Gaillardia.

Eupatorium

Yucca.

Butterfly Bush

Ribbon Grass

Hardy Asters, all varieties

Phlox Named Varieties.

Phlox Unnamed Varieties.

23 cts. each; 3 for 57 cts.

18 cts. each; 2 for 35 cts. 20 cts. each 40 cts. each

18 cts. each; $\$ 1.60$ per 12 $33 \mathrm{c}$ each; $\$ 3.25$ per 12

12 cts. each; 75 cts. per 12

.13 cts. each; $\$ 1.10$ per 12

.55 cts. each; $\$ 4.65$ per 12

.55 cts. each; $\$ 4.65$ per 12

.30 cts. each; $\$ 2.65$ per 12

30 cts. each; $\$ 2.65$ per 12

20 cts. each; $\$ 1.65$ per 12

30 cts. each; $\$ 2.65$ per 12

30 cts. each; $\$ 2.65$ per 12

30 cts. each; $\$ 2.65$ per 12

18 cts. each; $\$ 1.60$ per 12

18 cts. each; $\$ 1.60$ per 12

18 cts. each; $\$ 1.60$ per 12

35 cts. each

.55 cts. each

18 cts. each; $\$ 1.60$ per 12

25 cts. each; $\$ 2.15$ per 12

30 cts. each; $\$ 2.60$ per 12

25 cts. each; $\$ 2.10$ per 12 
$\stackrel{\leftrightarrow}{0}$

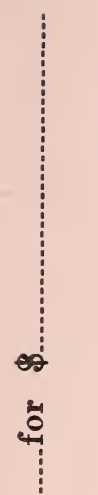

(7)

A

(7)

ค

a s.

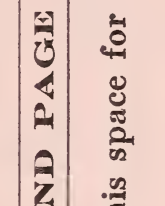

를

0 峞

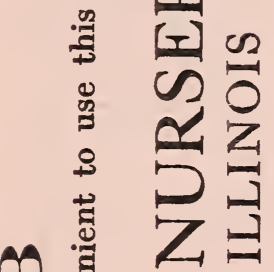

Q)
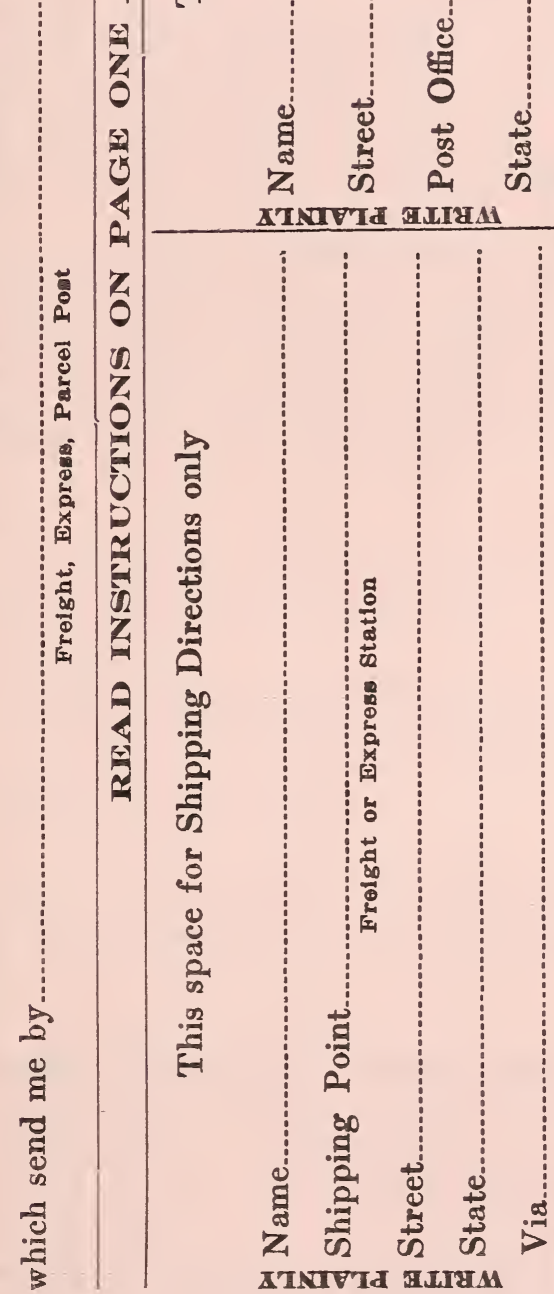

:

造

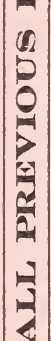

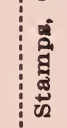

ơ

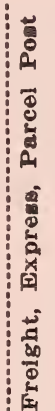

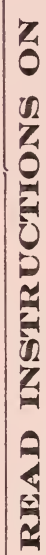

XINTEI MUIYA

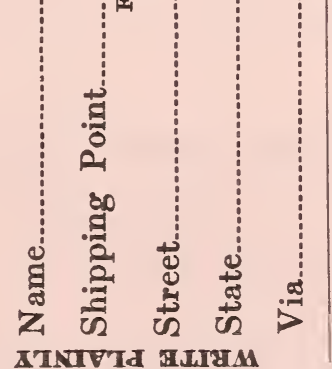




\section{PAEONIES}

Festiva Maxima

each $57 \mathrm{c}$

L'Esperence each $52 \mathrm{c}$

Gen. Bertrand

each $52 \mathrm{c}$

Felix Grouse

each $82 \mathrm{c}$

Rubra Superba each $67 \mathrm{c}$

\section{CANNAS}

$18 \mathrm{c}$ each $-\$ 1.65$ per 12

\section{DAHLIAS}

25 c each-\$2.15 per 12

\section{GLADIOLIS}

Named Varieties $13 \mathrm{c}$ each $-\$ 1.10$ per 12

Mixture $10 \mathrm{c}$ each-95c per 12

Descriptions of all the varieties listed under these prices will be found in the catalogue.

\section{TOMATO AND CABBAGE PLANTS}

$18 \mathrm{c}$ per Dozen- 6 Doz. or more $15 \mathrm{c}$ per Doz. Postpaid

Tomato.-Earliana,- - the earliest good sort.

Ponderosa,- - next in season, ponderous size.

Stone,-late sort, main canning variety.

Cabbage.-Early Jersey Wakefield, popular early sort.

Flat Dutch,- - the good late sort.

Plants ready after May first, or sooner if weather is right.

TREE PLANTING-Cut all of the side limbs back to two or three buds and shorten the top; make the holes plenty large so as not to crowd the roots and plant 3 inches deeper than they grew in the nursery. See that the roots are well spread out; use surface soil for filling, pressing it firmly around them; do not hurry the job; do it well and success is certain. Trees and plants should not be long exposed to the sun and air. Never put manure in the holes next to the roots, it causes decay. Plant strawberries with spade or dibble; spread roots out fan shape.

TRUE ECONOMY-It will always be found to be true economy to buy the very best trees, plants, etc., as to quality, that can be had. They need not be the largest stock, but stock that is guaranteed to be first-class as to quality and free from disease and injurious insects.

A first-class fruit tree is one that is healthy, well-grown, well dug and free from disease and injurious insects. Other things being equal, it is best to select a tree one or two years old. Older trees may be successfully planted, but the younger ones, are more satisfactory, are handled more easily, suffer less in transplanting and are more profitable in the long run.

Early ordering is to the advantage of the buyer because he can get the varieties ordered.

When sending in an order, always state mode of shipment.

If stock, when packed for shipment does not exceed 100 pounds in weight, it is better to ship by express, so that the stock need not be out of the ground long.

\section{Proper Distance Between Trees and Plants}

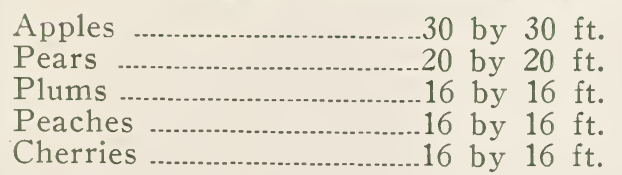

Raspberries 2 by $8 \mathrm{ft}$ Blackberries ................................. 2 by $8 \mathrm{ft}$

Strawberries and Asparagus

16 in. in rows $4 \mathrm{ft}$. apart

The number of plants required for an acre may be ascertained by dividing the number of square feet in an acre $(43,560)$, by the number of square feet given to each plant. 


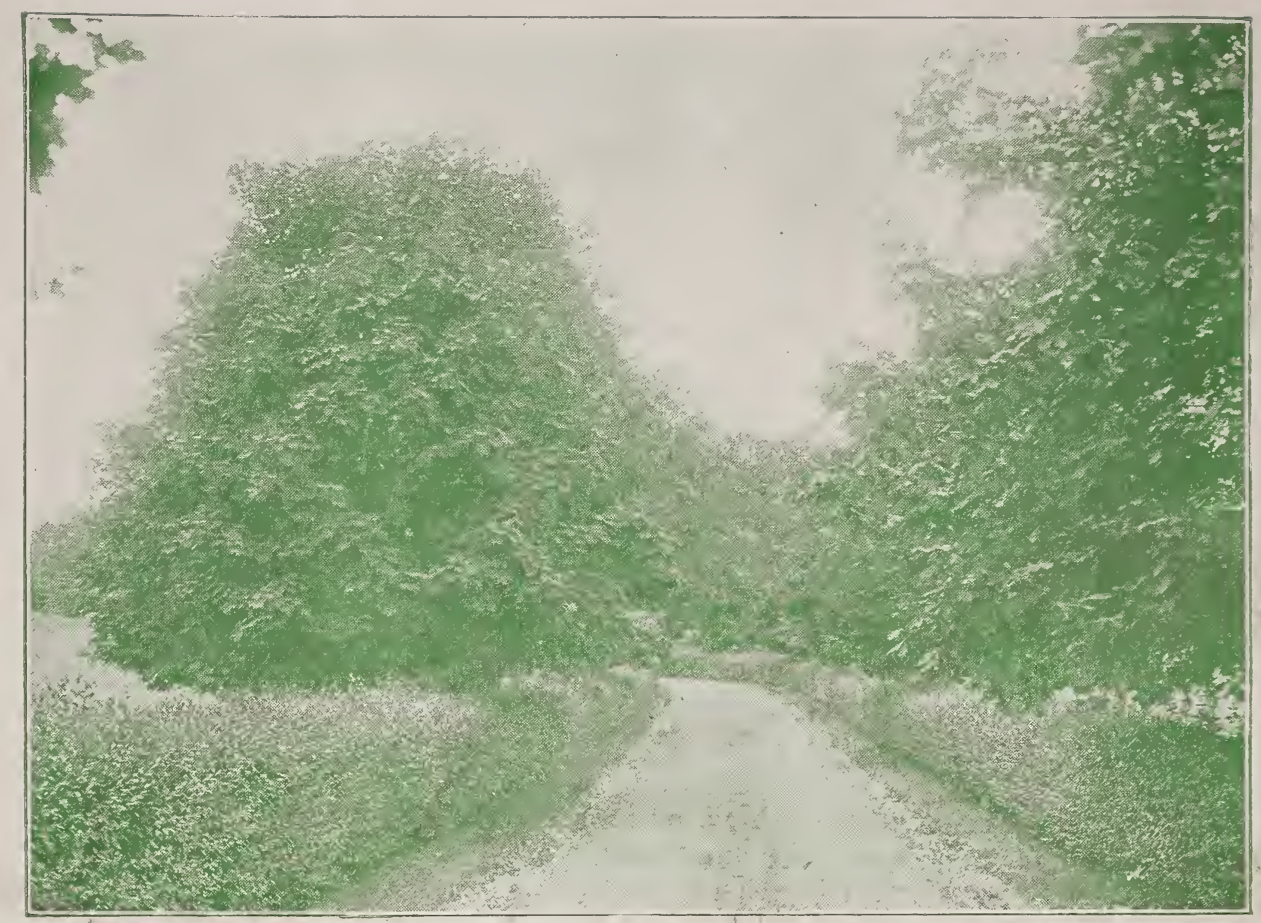

Privet Hedge and Norway Maples

\section{Landscape Gardening}

ANDSCAPE GARDENING or home beautifying has passed being just for a 2. few. Nearly everyone is now beautifying their home grounds with trees, shrubs or plants, or thinking of doing so.

Planting a home is not an expense, but a profitable investment. It pays divi* dends of satisfaction; it does not require new tires, nor eats gasoline; its value increases with age and never has to be renewed.

We have lately purchased a supply of handsome booklets on Home Beautifying, which we propose to give away to prospective customers. If you are interested in improving the appearance of your home we will gladly send you one of the books, if you will drop us a card.

Our Annual catalogue contains a large assortment of shrubs, trees, and hardy flowers, if you prefer to buy by mail; or our landscape gardener will confer with you at your home, or you will be welcome at our office.

If you wish, we can make the planting plans, furnish the shrubbery, trees and plants, deliver and plant them.

It will pay you to investigate our Landscape service and get our estimates.

Do not wait until planting time. DO IT NOW and be ready to plant at planting time.

\section{A L PHA N UR SER Y Alpha, Illinois}

\section{nursery Stock of Quality that bears the Choicest}

